\title{
22. UPPER CRETACEOUS PLANKTONIC FORAMINIFERS AND BIOSTRATIGRAPHY, LEG 120, SOUTHERN KERGUELEN PLATEAU 1
}

\author{
Patrick G. Quilty²
}

\begin{abstract}
Ocean Drilling Program Leg 120 Sites 747, and 750, and Hole 748C on the southern Kerguelen Plateau contain Cretaceous marine sections that span the upper Cenomanian-upper Maestrichtian. The most complete sections recovered from Sites 747 and 750 are Campanian and Maestrichtian. Older sections are fragmentary and only spot ages and paleotemperature indications can be determined. The section in Hole $748 \mathrm{C}$ lacks age-diagnostic planktonic species, and was deposited under very shallow marine conditions.

Water temperature was temperate (perhaps in the Transitional Faunal Province in Sliter's sense) with keeled globotruncanids present through the Cenomanian-Santonian. Faunas in the upper Campanian and into the Abathomphalus mayaroensis Zone of the upper Maestrichtian, may be placed in the Austral Faunal Province. In the upper part of the A. mayaroensis Zone, temperatures were significantly higher with quite diverse globotruncanids and more complex biserial taxa at the location of Site 750. Waters at Site 750, to the south and east of Site 747, may have been warmer during the Upper Cretaceous, reflecting the presence of a counterclockwise gyre east of the Kerguelen Plateau.
\end{abstract}

\section{INTRODUCTION}

This paper records the distribution of planktonic foraminifers from the three Cretaceous sections drilled during Ocean Drilling Program (ODP) Leg 120 (Table 1 and Fig. 1). These records then provide the basis for the foraminifer biostratigraphy of the Leg 120 sites. This paper is a companion to those by Watkins (this volume) on calcareous nannoplankton and Quilty (Chapter 23, this volume) on benthic foraminifers. It provides the detailed basis for the stratigraphic results published in Schlich, Wise, et al. (1989) from the same sections.

Unfortunately, core recovery at Site 750 was poor below the Maestrichtian. The section sampled from Site 747 yielded a good picture of the faunal structure for the lower Maestrichtian and comparison of the patterns over the same time interval at the two sites would have been valuable. Information from the two sites can be integrated to outline the history of faunal change (reflecting water-temperature change) through virtually the entire Maestrichtian. Little significance can be attributed to faunas older than the Maestrichtian except to suggest that the older Campanian and Cenomanian/Turonian reflect warmer conditions than the lower Maestrichtian.

\section{Previous Studies}

Quilty (Chapter 62, this volume) provides a detailed review of previous studies of micropaleontology of the Indian Ocean basin, lacking only the latest Ocean Drilling Program results that were not available at the time of writing. The only previous studies of planktonic foraminifer faunas from the Kerguelen Plateau region are by Quilty (1973) and by Bassias et al. (1987). Herb and Scheibnerova (1977, fig. 1) illustrate how little information was available from the area before the advent of the Ocean Drilling Program.

\footnotetext{
${ }^{1}$ Wise, S. W., Jr., Schlich, R., et al., 1992. Proc. ODP, Sci. Results, 120: College Station, TX (Ocean Drilling Program).

2 Australian Antarctic Division, Channel Highway, Kingston, Tasmania, Australia, 7050.
}

Huber (1991a) has reviewed the developmental history of the faunal provinces concept, as it applies to the higher southern latitudes, particularly in relation to the Austral Faunal Province (AFP), which is the faunal province relevant to the cooler southern-latitude faunas. Previously, Huber (1988) reviewed the species concepts of the most important species recorded, and, to a large extent, his species concepts are used for comparison. Many of his results are appropriate to the faunas described here, although temperatures may have been a little higher and thus faunas a little more diverse over the Kerguelen Plateau during the latest Maestrichtian. Trends in Kerguelen Plateau planktonic foraminifer faunal structure are parallel in time to those on the Maud Rise.

\section{MATERIALS AND METHODS}

The techniques of sample preparation are outlined in Quilty (Chapter 23, this volume). The only significant difference for this study is that, in addition to the routine examination for standard numbers (about 300 specimens from each sample) of benthic and planktonic forms, many samples were studied from a larger quantity of sample to identify species other than those that occurred in the standard picked samples. This is because planktonic faunas consist generally of few species, the key stratigraphically significant forms are rarer and often were not recovered from the first sample examination. One sample was routinely studied from each section taken (maximum $=7$ sections plus a core catcher sample). In key sections, or when recovery was poor, extra samples were processed.

Thus, the distribution tables (Tables 2-4) record those forms that are significant components of the fauna and in addition, those key species that are recorded by presence only, not by abundance. Samples near stratigraphic boundaries based on planktonic faunas were studied in more detail than samples from the intervening sections.

\section{Zonal Scheme Employed}

Because of the lack of continuous sequences over long intervals in this area, as seems typical of the Indian Ocean Basin (Quilty, Chapter 62, this volume), there is no local, widely applicable zonation. Hence an attempt has been made 
Table 1. Location and water depth of ODP Leg 120 sites from which Cretaceous sections were recovered.

\begin{tabular}{lccccc}
\hline Site & $\begin{array}{c}\text { Latitude } \\
\left({ }^{\circ} \mathrm{S}\right)\end{array}$ & $\begin{array}{c}\text { Longitude } \\
\left({ }^{\circ} \mathrm{E}\right)\end{array}$ & $\begin{array}{c}\text { Water depth } \\
(\mathrm{m})\end{array}$ & $\begin{array}{c}\text { Top } \\
\text { Cretaceous } \\
(\mathrm{mbsf})\end{array}$ & $\begin{array}{c}\text { Base } \\
\text { Cretaceous } \\
(\mathrm{mbsf})\end{array}$ \\
\hline 747 & $55^{\circ} 48.66^{\prime}$ & $76^{\circ} 64^{\prime}$ & $1696-1707$ & 181.5 & 295.1 \\
748 & $58^{\circ} 26.45^{\prime}$ & $7^{\circ} 58.89^{\prime}$ & 1301 & 407.0 & 902.0 \\
750 & $57^{\circ} 35.54^{\prime}$ & $8^{\circ} 14.37^{\prime}$ & 2030.5 & 355.8 & 623.5 \\
\hline
\end{tabular}

to apply zonal schemes developed elsewhere, especially that of Huber (1991a). The application of schemes other than Huber's is not wholly satisfactory because most such zonal schemes were developed for warmer climates, more continuous sequences and many key species are absent from the cooler water, higher latitude sections.

\section{Abathomphalus mayaroensis Zone}

This is characterized by the presence of the nominate species (A. mayaroensis) accompanied, in its upper portion, by a diverse fauna of Globotruncana sensu lato and abundant biserial forms. Faunas vary greatly from sample to sample, indicating rapidly changing environments, probably water temperature. This zone has been identified only in Hole 750A. The first appearance datum (FAD) of the nominate species is at Sample 120-750A-18R-CC (384.7 mbsf), and it continues in that section to the top of the Cretaceous at $120-750 \mathrm{~A}-15 \mathrm{R}-\mathrm{CC}$ ( $355.8 \mathrm{mbsf}$ ). This usage is consistent with the definition of the zone employed by Huber (1991a).

\section{Globotruncanella havanensis Zone}

Huber (1991a) introduced this zone to include the lower Maestrichtian, that is, the section occurring between the

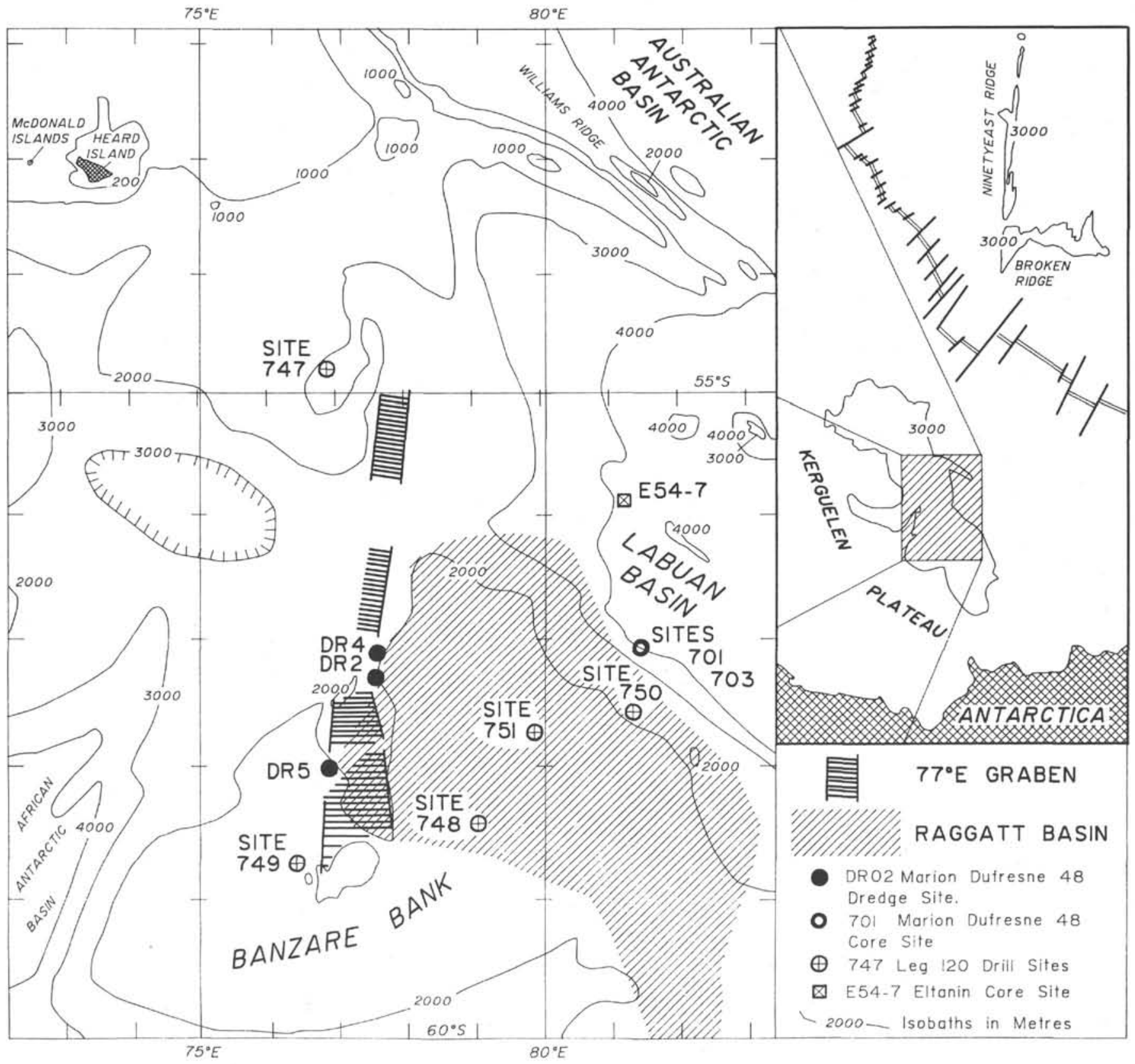

Figure 1. Locality map showing drill sites and major tectonic and geographic features 
Table 2. Distribution of species, Holes 747A and 747C.

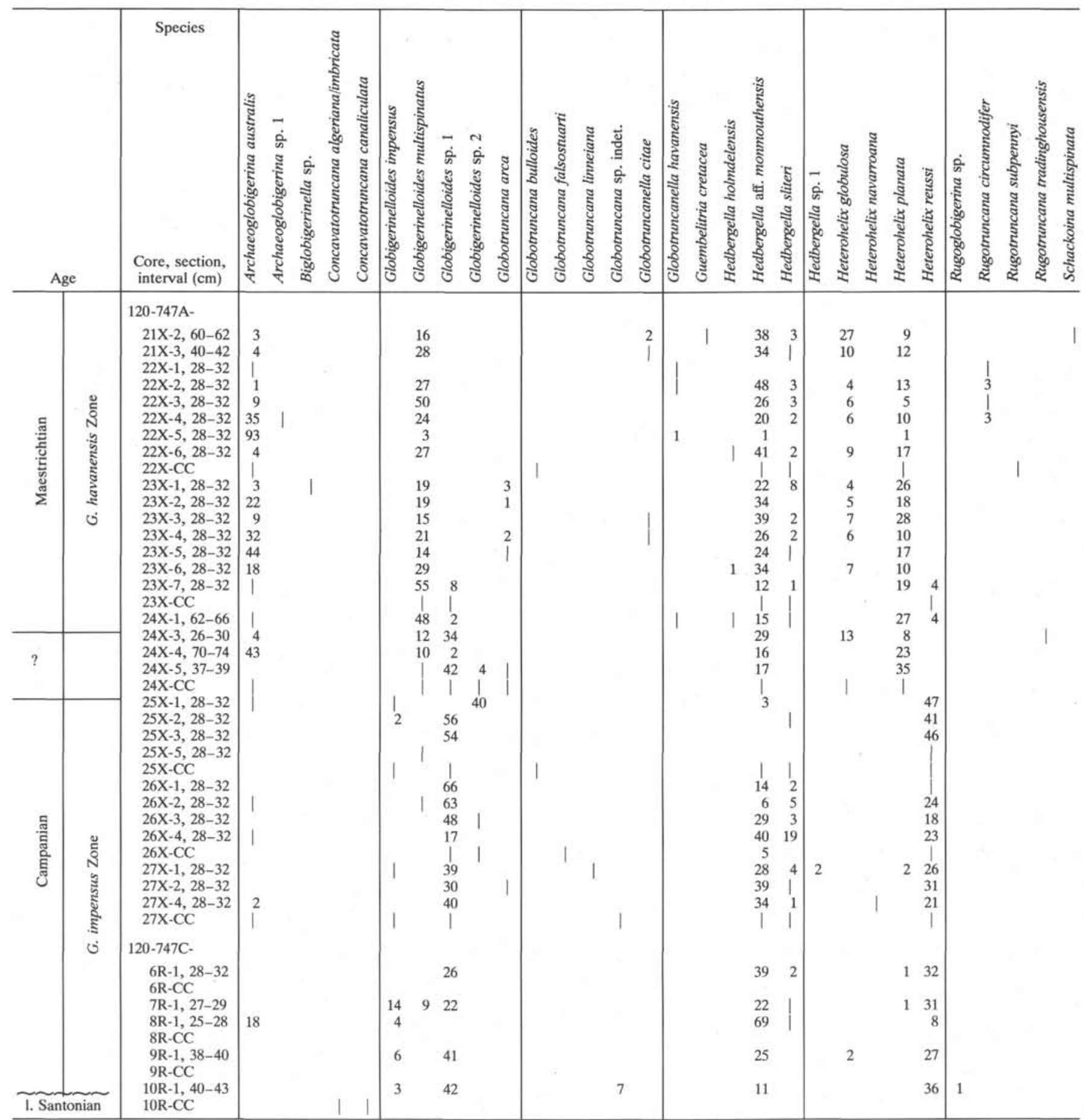

Notes: Wherever possible, percentages are given of the abundance of species within a sample. A thin vertical line indicates presence when percentage is $<1$, when sample numbers were too small for meaningful counts, or for samples that were picked for presence only. $\mathrm{R}=$ rotary core barrel, $\mathrm{W}=$ wash-core recovery (see text); $\mathrm{X}=$ extended core barrel.

extinction of Globigerinelloides impensus (marking the top of the Campanian) and the evolution of Abathomphalus mayaroensis species that define the neighboring zones. The G. havanensis Zone can be recognized in this study, and two intervals can be recognized within it. One can be correlated with the Gansserina gansseri Zone of warmer climates, and the other is undifferentiated lower Maestrichtian.

\section{Gansserina gansseri Zone}

This zone is generally thin and difficult to identify confidently. G. gansseri is absent, but the zone was identified on other bases. The boundary with the $A$. mayaroensis Zone above is easy to identify through the transition from common A. mayaroensis (above) to samples with $A$. intermedius (con- 
Table 3. Distribution of species, Hole 748C.

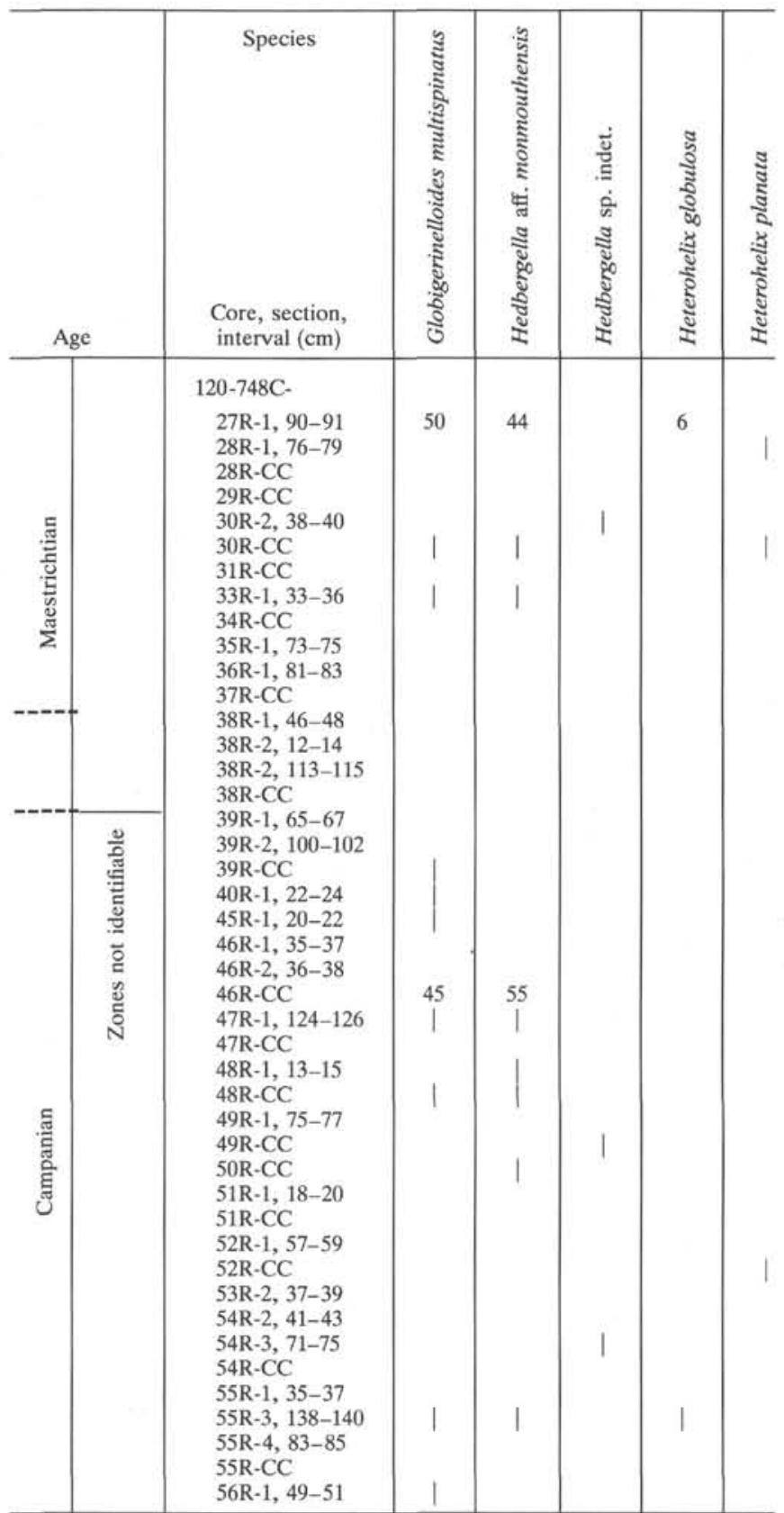

Notes: Explanation of symbols as for Table 2. Age given in the "Age" column is from the Initial Reports volume, not from the foraminifer fauna itself.

tinuing downhole to its FAD at Sample 120-750A-20R-1, 50-54 cm; $394.9 \mathrm{mbsf}$ ) and Globotruncanella citae (which occurs in Holes 747A and 750A) but lacking $A$. mayaroensis. The lower transition to the $G$. gansseri Zone is more difficult as the nominate species for both zones are absent. This problem is exacerbated by confusion over the ranges of Rugoglobigerina reicheli and Globotruncana stephensoni. Pessagno (1967), for example, suggests that these two species should have discrete ranges, but it appears that they overlap to some extent in this region.

If the FAD of Globotruncanella citae is taken as the base of the G. gansseri Zone and its continuing uphole occurrence without $A$. mayaroensis the extent of the zone, the boundary occurs in Hole 747A in the interval from Samples 120-747A-
$21 \mathrm{X}-2,60-62 \mathrm{~cm}$ (191.65 mbsf), to $-23 \mathrm{X}-4,28-32 \mathrm{~cm}(213.28$ mbsf), a thickness of $21.6 \mathrm{~m}$. It also occurs in Hole $750 \mathrm{~A}$ in the interval from Samples 120-750A-19R-1, 28-32 cm (384.98 mbsf), to -21R-1, 28-32 cm (404.28 mbsf), a thickness of 19.3 $\mathrm{m}$. This suggests a comparable rate of sedimentation in the two areas. It also allows correlation between the levels of the FADs in each hole, one of the few cases in the Cretaceous sections on this leg in which that can be accomplished.

\section{Undifferentiated Lower Maestrichtian}

No previously identified zonal scheme, other than as part of the Globotruncanella havanensis Zone of Huber (1991a), can be applied to the lower Maestrichtian, taken here to include the G. aegyptica and $G$. havanensis Zones of Caron (1985), which was compared with many other zonal schemes in review. The situation is much as that outlined by Huber (1991a) for the South Atlantic. Thus, the lower Maestrichtian is taken as the interval between the last appearance datum (LAD) of Globigerinelloides impensus and the FAD of Globotruncanella citae.

At Site 750, the LAD of G. impensus is at Sample 120$750 \mathrm{~B}-3 \mathrm{R}-1,18 \mathrm{~cm}$ ( $450.18 \mathrm{mbsf})$, and the highest sample below the base of the range of $G$. citae is at Sample 120-750A21R-CC (413.6 mbsf), a total thickness of $36.6 \mathrm{~m}$. In Hole $747 \mathrm{~A}$, this is included in the interval from Samples 120-747A$25 \mathrm{X}-1,28-32 \mathrm{~cm}$ (227.78 mbsf), to $-23 \mathrm{X}-5,28-32 \mathrm{~cm}(214.78$ mbsf), a thickness of only $13 \mathrm{~m}$. This suggests either much lower rates of sedimentation over this period, or the presence of short disconformities or diastems within the sequence.

\section{Globigerinelloides impensus Zone}

Huber (1990) established the G. impensus Zone and took the top of the zone to be within the lowest Maestrichtian. Later, he suggested that it is a useful Campanian/Maestrichtian boundary index, a view reinforced in Huber (1991a) where its LAD was dated as $75.1 \mathrm{Ma}$. It is used here in the role of a Campanian/Maestrichtian boundary index.

The FAD of $G$. impensus is not clearly identifiable in Leg 120 holes because of the poor sample control in the relevant part of the sections.

\section{Dating of Pre-Campanian Sections}

As noted above, dating of the older parts of the section is sporadic and poorly controlled.

At Hole 747A, the lowest sample (120-747C-10R-CC) may be lower Santonian or older (see below). At the base of the marine section in Hole $750 \mathrm{~B}$, the problem is different, in that the upper Cenomanian is documented with well-preserved specimens from a lithology not recovered in cores. Thus, faunal structure and total fauna are unknown. At Site 748, the Cretaceous section, although representing a significant part of the Upper Cretaceous on the basis of palynology, lacks all key planktonic foraminifer species, probably as a result of innercontinental-shelf conditions of deposition.

\section{SITE 747}

Holes 747A, 747B, and 747C were drilled at Site 747, and Cretaceous sediments were encountered in the interval 189.5$295.1 \mathrm{~m}$ below seafloor (mbsf), drilled in Holes 747A (189.5$256.0 \mathrm{mbsf})$ and $747 \mathrm{C}(181.5-295.1 \mathrm{mbsf})$. Basalt underlies the sediment section (Fig. 1 and Table 1).

The Cretaceous section, except for the deepest sample, is Campanian and lower Maestrichtian, and is composed of calcareous ooze throughout. Preservation usually is good without evidence of dissolution. Water depth at the time probably was several hundred meters shallower than now (Quilty, Chapter 23, this volume), and thus the area has never 
been below the carbonate compensation depth (CCD). Water depth was middle to lower bathyal during the Campanian/ lower Maestrichtian, and thus the faunas should contain the full diversity of planktonic species that existed throughout this time interval. Preservation varies from sample to sample, from excellent to moderate, in the sense used by Huber (1991a). Table 2 illustrates the distribution of species at this site.

There is a question as to the age of the oldest sediments sampled at Hole $747 \mathrm{C}$ in Core $120-747 \mathrm{C}-10 \mathrm{R}$. To date, these have been taken to be lower Santonian based on the calcareous nannoplankton (Watkins, this volume). Some elements of the foraminifer fauna are consistent with this age, especially Concavatotruncana canaliculata (Reuss). Very poorly preserved and, at the species level, unidentifiable forms belong to a group of species for whom the test form alone would suggest a slightly greater age, perhaps Turonian. The forms are part of a group including Praeglobotruncana stephani (Gandolfi), Concavatotruncana algeriana (Caron), and $C$. imbricata (Mornod). All are moderately high-spired, conical forms with carinate margins, flat ventral surfaces, and elevated, beaded sutures on part of the dorsal surface during the last whorl.

The Campanian/Maestrichtian boundary lies between Samples 120-747A-25X-1, 28-32 cm (227.78 mbsf), and -24X-1, 62-66 cm (218.62 mbsf). Globigerinelloides impensus Sliter occurs in samples as high in the section as Sample 120-747A$25 \mathrm{X}-1,28-32 \mathrm{~cm}$, and is taken as marking the top of the unequivocally Campanian part of the sequence, following Huber (1991a). The first uphole appearance of Globotruncanella at Sample 120-747A-24X-1, 62-66 cm, is taken as the oldest unequivocally Maestrichtian sample.

Hole $747 \mathrm{~A}$ contains virtually the entire Maestrichtian sequence encountered at this site, lacking the uppermost Maestrichtian and containing the lower Maestrichtian essentially complete, encompassed in some $62.6 \mathrm{~m}$. Figure 2 summarizes the structure of the planktonic foraminifer fauna, which is dominated throughout by three genera: Heterohelix, Hedbergella, and Globigerinelloides. Ornamented heterohelicids are absent, and, in places, Archaeoglobigerina australis Huber is an important element. Within each genus, one species is usually dominant, but up to three species of each may be present, especially in the case of Globigerinelloides, in which apparently unnamed species are present generally in small proportions and vary greatly from sample to sample. No faunas representative of anything other than the AFP (see Sliter, 1977, for definitions) were identified at this site.

Throughout the Campanian section, the three genera are approximately equally dominant until near the top, and, although proportions vary, there is no marked pattern in that variation. In the interval $233.78-229.28 \mathrm{mbsf}$ inclusive, $\mathrm{Hed}$ bergella virtually disappears for a short time; however, at the level where the lower Maestrichtian is positively identified, the three genera were again equally dominant, with Globigerinelloides slightly more dominant over Heterohelix. From that depth to the youngest part of the lower Maestrichtian, diversity increased to four equally dominant genera (Archaeoglobigerina becoming important) to about $200 \mathrm{mbsf}$, at which depth there is another reduction to three again by a decrease in the significance of Archaeoglobigerina.

If water temperature was the main determinant of diversity, and in the absence of oxygen isotope data, then this distribution implies a cooler interval between 240 and 225 mbsf than below or above, and a relatively "warm" interval within the AFP between 225 and 200 mbsf.

In Figure 2, the generic groups are identified. Globotruncanids such as two species of Globotruncanella ( $G$. citae and
G. havanensis) are present, but they are rare. Keeled globotruncanids usually are present but never common.

\section{SITE 748}

Of the three holes drilled at this site, only Hole $748 \mathrm{C}$ encountered a Cretaceous sequence (Fig. 1 and Table 1). The Cretaceous section is entirely marine and has been incorporated into lithologic Unit III, which was further divided into Subunits IIIA-IIIC (Schlich, Wise, et al., 1989).

This section is generally of shallow marine aspect (Quilty, Chapter 23, this volume) with evidence of water deepening with time. Planktonic foraminifers are less important components of the faunas, and perhaps diversity is not as great as in coeval sediments elsewhere in the region because of the shallow depth.

Preservation of all calcareous fossils generally is poor to moderate with all specimens stained amber in contrast to the clean white ooze specimens recovered from most samples at the other Leg 120 sites. Fine adherent matter is common, obscuring detail.

Planktonic foraminifers seldom exceed $1 \%$ of the total foraminifer fauna at this site and have essentially no role in defining the stratigraphic sequence. The fauna consists of the long-ranging forms Heterohelix globulosa, $\mathrm{H}$. planata, Hedbergella aff. monmouthensis, and Globigerinelloides multispinatus (Table 3). Specimens are small, and neither the full range of variation within the fauna nor within any individual species is developed, another feature consistent with the suggested water depth of $<50 \mathrm{~m}$. This water depth is supported by features of the benthic foraminifers and other elements of the benthic fauna and also some sedimentologic characteristics (Quilty, Chapter 23, this volume).

\section{SITE 750}

Holes $750 \mathrm{~A}$ and $750 \mathrm{~B}$ were drilled at Site 750 , for a total sub-bottom penetration of $709.7 \mathrm{~m}$ (Fig. 1 and Table 1). Drilling difficulties led to poor recovery in the lower part of the Cretaceous section. Samples were generally highly lithified and were disaggregated with considerable difficulty, yielding imperfectly preserved material. In addition to the normal samples from each section, the dark gray, plastic mud adhering to the core was carefully removed, washed, and examined in Section 120-750B-11W-2. This yielded very rare but wellpreserved Praeglobotruncana delrioensis (Plummer) and Concavatotruncana imbricata (Mornod), proving that there is a Cenomanian and Turonian section that was not sampled properly in the coring process. Separate samples were processed from the dark- and light-colored lithotypes of the lower cores in this hole, and these are recorded in Table 4 as Samples 120-750B-11W-dark or 120-750B-11W-light in reference to the lithology color. The exact locality of the sample from the core or cored interval is unknown.

Although age equivalents of the fauna documented by Quilty (1973) were recovered, the total fauna was not seen and thus no detailed comparison is possible.

Figure 3 summarizes the faunal structure. Data below Core 120-750B-6W (507.9 mbsf) are not good and, although plotted on Figure 3, should not be relied upon in detail. They should be used only to indicate that Globigerinelloides is more dominant at that depth to an extent rare in the shallower parts of the section. In this interval preservation is poorer as evident from the fact that a significant proportion of the fauna is unidentifiable. The samples also disaggregated less readily. In addition, there is considerable doubt concerning the location of some samples within the section. This is borne out best by the positive identification of Cenomanian in mud, but not in the lithified sample. 


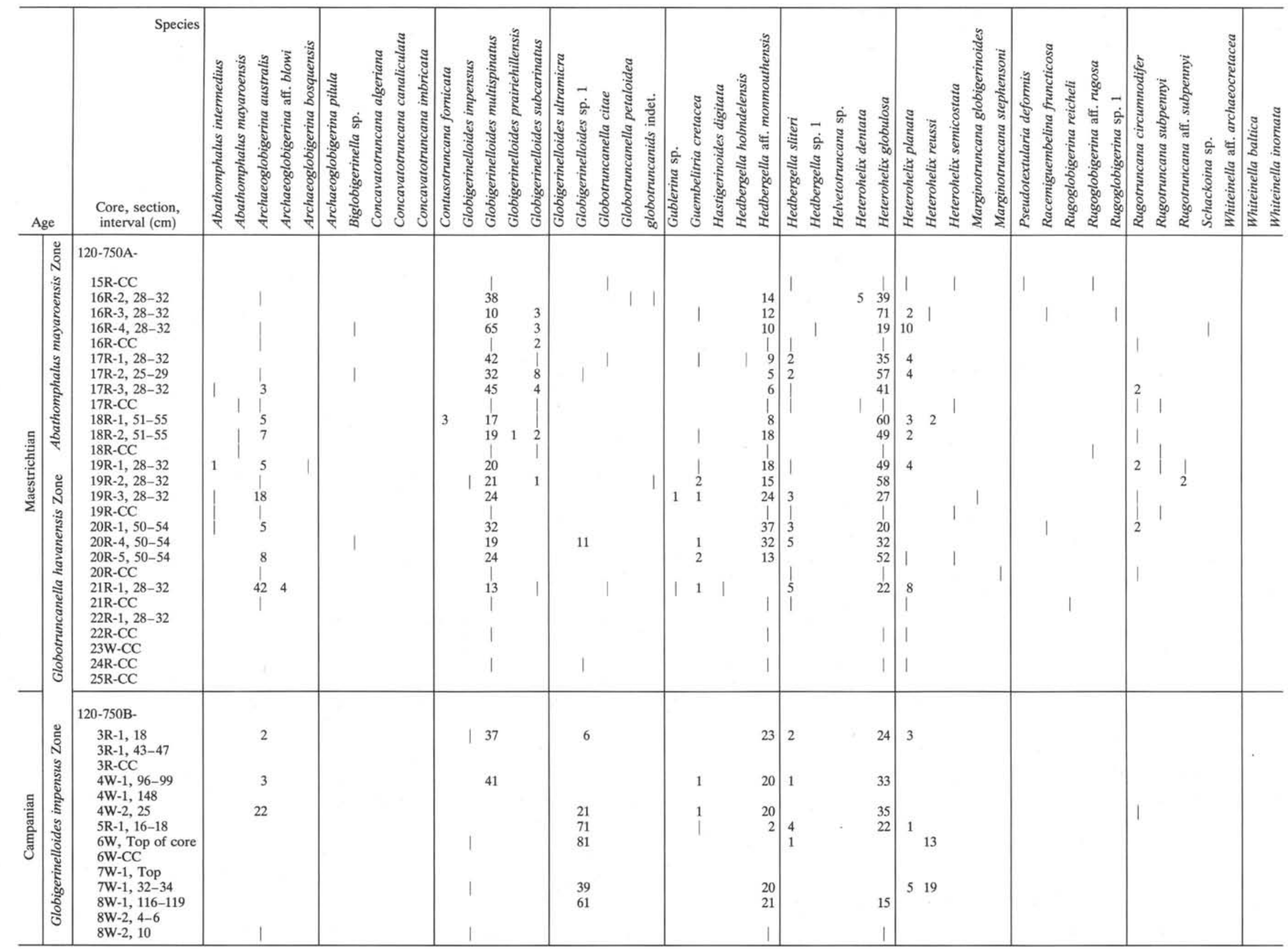


Table 4 (continued).

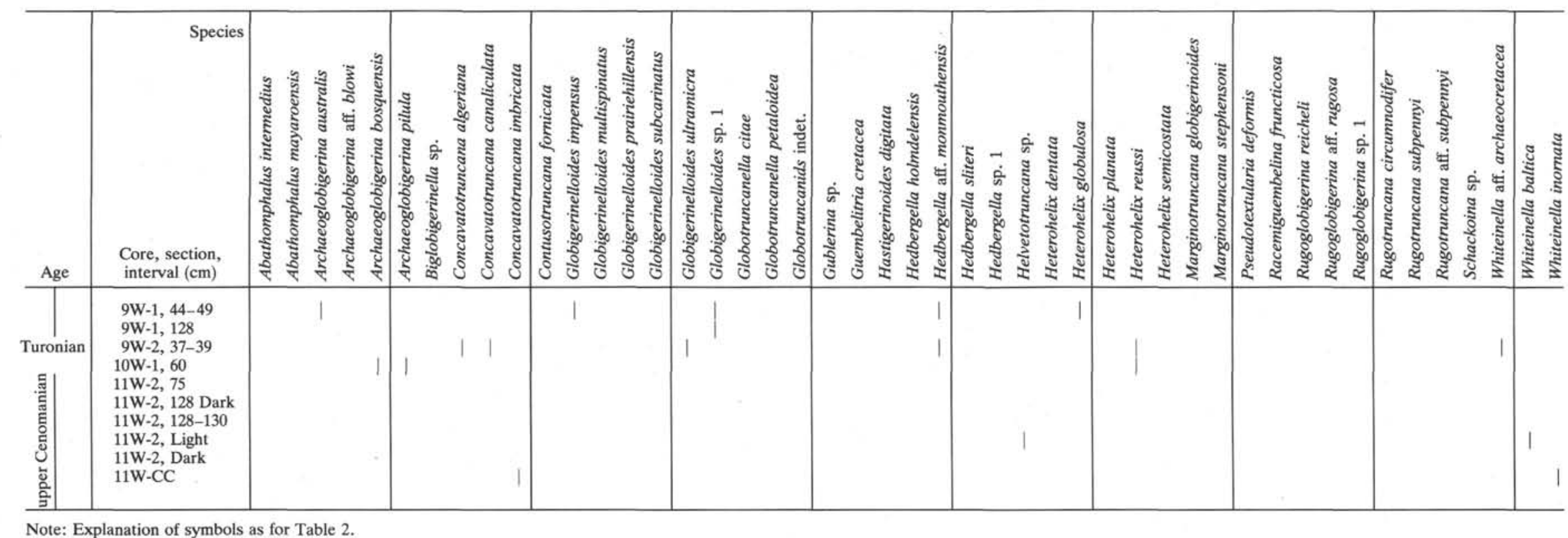




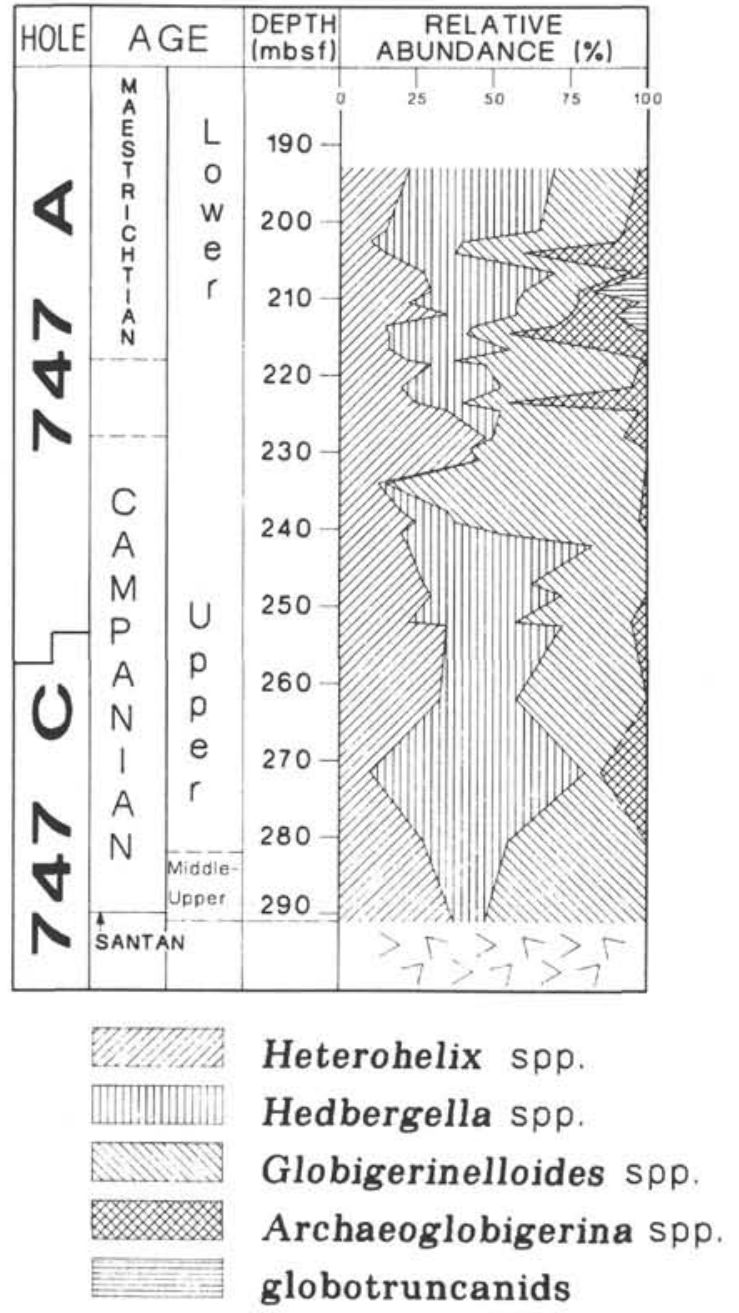

Figure 2. Relative abundance of the main species groups in the planktonic fauna through the section at Site 747 .

The faunas in the upper Maestrichtian are more diverse than in the lower Maestrichtian at Site 747. Several globotruncanid species are present consistently, and both Gublerina and Racemiguembelina are recorded, albeit very rarely. Faunas in this section are consistent with allocation to the Transitional Faunal Province (TFP), probably a result of warmer waters in the vicinity during the late Maestrichtian, than in the early Maestrichtian. They are, with the exception of those in Sample 120-750A-15R-CC, not fully developed Transitional faunas, but they are notably more diverse than the Austral faunas in the lower Maestrichtian at Site 747. As Site 750 is significantly farther south than Site 747 , it is to be expected that at the latter site, coeval waters would have been even warmer and the contrast between lower and upper Maestrichtian faunas even more marked.

Sedimentation rates are difficult to calculate because most zones are incomplete, lacking either the basal or top markers. The Globotruncanella havanensis Zone is an exception and, using the boundaries discussed earlier, a sedimentation rate of $13 \mathrm{~m} / \mathrm{m} . \mathrm{y}$. is calculated for the interval 75.1-69.86 m.y., using the ages of relevant FADs given by Huber (1990) (Table 3).

The fauna in Sample $120-750 \mathrm{~A}-15 \mathrm{R}-\mathrm{CC}$ is the youngest Maestrichtian recorded from Leg 120 sites and is decidedly warmer in aspect than those from other samples. Pseudotextularia deformis (Kikoine) and Heterohelix semicostata (Cushman) occur only here and are species typical of the

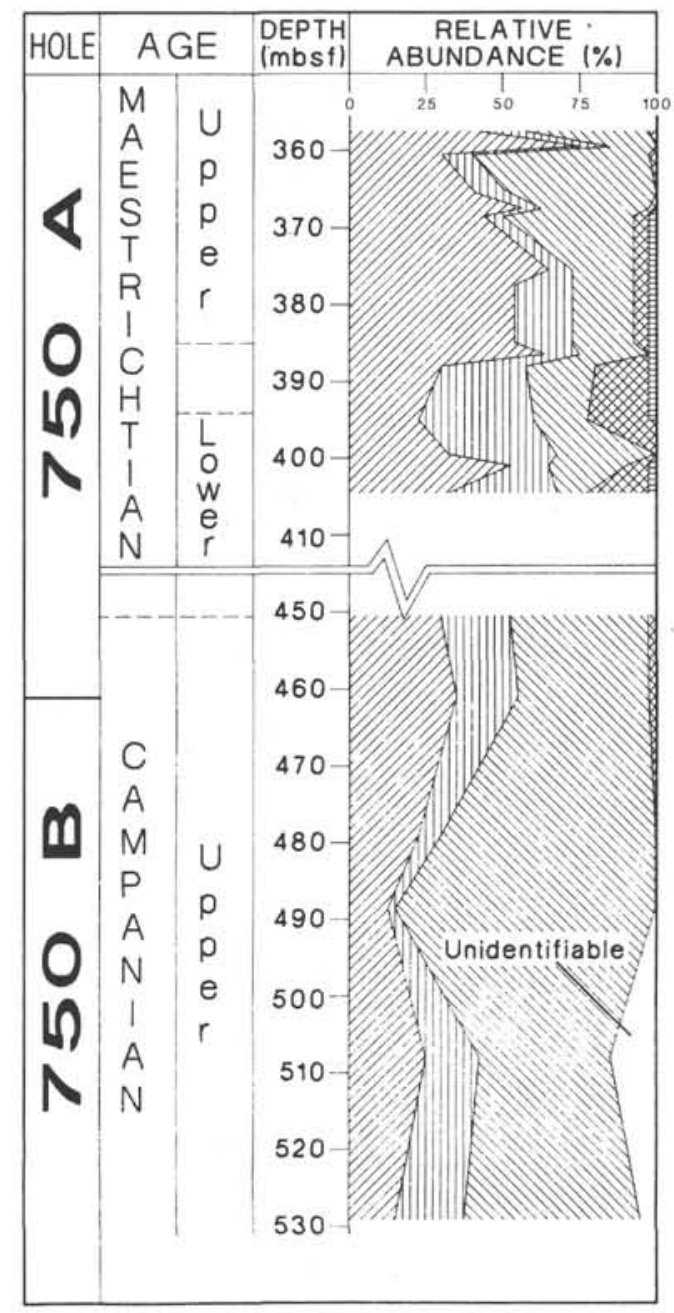

Figure 3. Relative abundance of the main species groups in the planktonic fauna at Site 750 . Key is the same as for Figure 2. The break in the graph between 410 and 450 mbsf indicates that there are no reliable figures available between those depths.

warmer parts of the TFP. Forms similar to Rugotruncana subcircumnodifer occur in this section, and thus all features of the planktonic foraminifer fauna imply quite warm conditions. The Tertiary sequence overlies the Cretaceous with an unconformity.

As at Site 747 , the faunas are dominated by three genera: Heterohelix, Hedbergella, and Globigerinelloides. Hedbergella is less significant and makes up a constant proportion of the faunas. Heterohelix is normally dominant, losing some dominance toward the top of the sequence as Globigerinelloides gains. The proportion of the Transitional element is always low, normally about $2 \%-5 \%$ of the total planktonic fauna.

In the section allocated to the Campanian on the basis of the presence of $G$. impensus, the same three genera are present and make up essentially the entire fauna. Below that part of the section for which figures are plotted, there are significant numbers of globotruncanid species that are consistent with a well-developed Transitional fauna or even warmer. However, the samples are so poor that it is not worth plotting their structure on the diagram.

The stratigraphic relationships at the base of the marine section in Hole $750 \mathrm{~B}$ are still uncertain. There is clear evi- 
dence of a Cenomanian-Turonian element in the faunas, but much younger species, especially Globotruncana linneiana (d'Orbigny), are present. Whether this reflects reworking of the Cenomanian/Turonian into a younger section, structural complexity causing the presence of thin units of younger rocks in an older section, or downhole contamination, is unclear as yet.

Even though there is difficulty in unraveling the stratigraphic relationships at the base of the marine section at this site, there is clear evidence that the Cenomanian-Turonian fauna, although poorly preserved and rare, contains a higher proportion of the total species range in existence at the time, than does the upper Campanian/lower Maestrichtian. Thus, it seems that water temperatures then were higher than in the later interval.

\section{History of Cretaceous Regional Water Temperature}

Throughout the interval when Sites 747 and 750 were accumulating sediment columns, Site 750 was bathed in water a little warmer than that at Site 747 , even though Site 747 is more northerly and thus could be expected to have been warmer. A possible explanation lies in the paleogeography. If the Kerguelen Plateau was considerably shallower than at present, it may have acted as an effective barrier to water flow from west to east, at the same time that it deflected easterly flowing water from the west to the north or northeast between eastern Africa and India to the equatorial regions, or between eastern India and the Ninetyeast Ridge (perhaps high and vegetated at the time, as was the case during significant parts of the Tertiary; Kemp and Harris, 1975) and to the tropics as well.

If the plateau was such a barrier, it may have allowed the development in the Australian-Antarctic and Wharton Basins of a counterclockwise gyre, which would have brought warmer water to the eastern side of the plateau, including the location of Site 750 .

The youngest Cretaceous sample studied (120-750A-15R$\mathrm{CC}$ ) is the most diverse with regard to the planktonic foraminifer fauna; it represents significantly warmer conditions than can be identified throughout the other sections studied. It occupies a very short part of the A. mayaroensis Zone and suggests a marked warming immediately before the termination of the Cretaceous. This is consistent with the generalization made by McGowran (1974) and repeated by Herb and Scheibnerova (1977). Below that depth in the Maestrichtian and in the Campanian, faunas are much less diverse and lack many keeled forms, all consistent with an explanation of cooler water faunas.

Older samples (e.g., the lower Santonian or older in Hole 747 B and the Cenomanian-Turonian in Hole 750B) all contain faunas with keeled species and are sporadically, despite poor preservation and sample availability, more diverse than those from the Campanian/lower Maestrichtian, consistent with warmer conditions at the earlier time (Quilty, 1973).

\section{TAXONOMY}

Order FORAMINIFERIDA Eichwald, 1830

Suborder GLOBIGERININA Delage and Herouard, 1896

Superfamily HETEROHELICACEA Cushman, 1927

Family HETEROHELICIDAE Cushman, 1927

Genus HETEROHELIX Ehrenberg, 1843

Heterohelix dentata Stenestad, 1968

(Plate 1, Fig. 2)

Heterohelix dentata Stenestad, 1968, p. 67, pl. 1, figs. 3-6, 8-9, and 11 ; pl. 2, figs. 1-3.

Heterohelix dentata (Stenestad) Huber, 1990, p. 503, pl. 1, fig. 2.
Remarks. As noted by Huber (1990), care must be taken in differentiating this species from the better known $H$. glabrans (Cushman). This form occurs in the higher parts of the Upper Cretaceous section at Site 750 . Although normally typical of the species, occasional specimens are more flabelliform and approach Gublerina.

$$
\text { Heterohelix globulosa (Ehrenberg), } 1839
$$

(Plate 1, Figs. 3-4)

Textularia globulosa Ehrenberg, 1839, p. 135, pl. 4, figs. 2B, 4B, 5B, $7 \mathrm{~B}$, and $8 \mathrm{~B}$.

Heterohelix globulosa (Ehrenberg) Bandy, 1967, p. 23, fig. 13, 5.

Heterohelix globulosa (Ehrenberg) Quilty, 1973, p. 363.

Heterohelix globulosa (Ehrenberg) Huber, 1990, p. 503, pl. 1, figs. 3 and 4 .

Remarks. This is one of the dominant planktonic foraminifers in the youngest parts of the Cretaceous section. In Hole $750 \mathrm{~A}$, rare specimens approach Gublerina in having a flabelliform growth pattern with globular inflated chambers that have the typical $H$. globulos $a$ fine striations.

\section{Heterohelix aff. moremani (Cushman), 1938}

(Plate 1, Fig. 5)

?Guembelina moremani Cushman, 1938, p. 10, pl. 2, figs. 1-3.

?Heterohelix moremani (Cushman) Pessagno, 1967, p. 260, pl. 48, figs. $10-11$; pl. 89 , figs. 1 and 2 .

?Heterohelix moremani (Cushman) Bandy, 1967, p. 22, fig. 111.

Remarks. This form is very rare and is elongated with fine striations. The test form is reminiscent of $H$. moremani, which is marked by clearly depressed sutures, inflated chambers, and gently tapering test. The question marks in the synonymy are to indicate that I am not sure that the reference is to the same species as is recorded here.

\section{Heterohelix navarroensis Loeblich, 1951} (Plate 1, Fig. 6)

Heterohelix navarroensis Loeblich, 1951, p. 107, pl. 12, figs. 1-3. Heterohelix navarroensis (Loeblich) Pessagno, 1967, p. 261, pl. 89, figs, 8-9.

Remarks. This very rare form is identified tentatively because the characteristic initial coil has not been observed and because there are no obvious striations on the few specimens seen. The identification is based partly on the distinctive gross growth form.

\section{Heterohelix planata (Cushman), 1938}

(Plate 1, Fig. 7)

Guembelina planata Cushman, 1938, p. 12, pl. 2, figs. 13-14. Heterohelix pulchra (Cushman) Sliter, 1977, p. 541, pl. 6, figs. 7-9. Heterohelix planata (Cushman) Huber, 1990, p. 503, pl. 1, figs. 5-6.

Remarks. This species is an important element of the Campanian/ Maestrichtian faunas. It develops a few short longitudinal ribs in the earlier part of the test at the lower/upper Maestrichtian boundary (between Cores 120-750A-20R and -21R) where it evolves into Heterohelix semicostata (Cushman), which becomes a minor part of later faunas. The boundary between the two species is subjective.

\section{Heterohelix reussi (Cushman) , 1938 \\ (Plate 1, Fig. 8)}

Guembelina reussi Cushman, 1938, p. 11, pl. 2, figs. 6a-b. Heterohelix reussi (Cushman) Caron, 1985, p. 60, fig. 24, 10-11.

Remarks. Heterohelix reussi evolved into $H$. globulosa at approximately the boundary between Cores $120-747 \mathrm{~A}-24 \mathrm{X}$ and $-25 \mathrm{X}$. A population of variable but generally thick specimens with inflated chambers changes into one which is less variable, with less inflated chambers and an overall test shape that is thinner.

Individual specimens below Core $120-747 \mathrm{~A}-24 \mathrm{X}$ may be referred to $H$. globulosa; however, on a population basis, they are better identified as $H$. reussi.

\section{Heterohelix semicostata (Cushman), 1938}

(Plate 1, Fig. 9)

Guembelina semicostata Cushman, 1938, p. 16, pl. 3, fig. 6 . 
Heterohelix semicostata (Cushman) Pessagno, 1967, p. 263, pl. 98, fig. 21.

Remarks. There are several well-preserved specimens of this distinctive but rare species in the youngest Maestrichtian at Sample $120-750 \mathrm{~A}-15 \mathrm{R}-\mathrm{CC}$. Thus, they are younger than the youngest record of Pessagno (1967), which strengthens his statement that it may never be a good index fossil. I agree with his comment that this species seems to be transitional between Heterohelix and Gublerina.

\section{Heterohelix sp. \\ (Plate 1, Fig. 10)}

Remarks. A few well-preserved but probably incomplete specimens. They are compressed, with chambers increasing rapidly in size. They may be juveniles of Gublerina compressa (van der Sluis) as the last few chambers have the characteristic Gublerina features. The early chambers lack anything more than fine striations and thus can be differentiated from the ornamented forms of Gublerina. These forms are more flabellate than the specimen referred below to Gublerina sp., and they lack the ornament at the base of the specimen.

\section{Genus RACEMIGUEMBELINA Montanaro Gallitelli, 1957}

\section{Racemiguembelina fructicosa Egger, 1902}

(Plate 1, Fig. 12)

Guembelina fructicosa Egger, 1902, p. 35, pl. 14, figs. 8-9.

Racemiguembelina fructicosa (Egger) Montanaro Gallitelli, 1957, p. 142 , pl. 32 , figs. $14-15$.

Racemiguembelina fructicosa (Egger) Caron, 1985, p. 67, fig. 24, 22-23.

Remarks. The single specimen is not a typical example of the species as the characteristic proliferation of globular chambers is represented by only two such chambers. The species does warrant inclusion in Racemiguembelina and the recognition that conditions in the vicinity at the time were marginally suitable for the existence of the species there.

\section{Genus GUBLERINA Kikoine, 1948}

Gublerina sp.

(Plate 1, Fig, 13)

Remarks. A single specimen is allocated unequivocally to Gublerina. Its specific identity is in doubt, however, because of the nature of the ornament on the early chambers. That ornament, near the periphery, consists of very few short ribs and more numerous pustules, which form the basis for its differentiation from Heterohelix sp. discussed above. The predominance of the latter suggests an affinity closer to $G$. glaessneri Brönnimann and Brown than to $G$ decoratissima (de Klasz). Later chambers have a fine striated surface, common in many species of Heterohelix.

\section{Superfamily PLANOMALINACEA Bolli, Loeblich and Tappan, 1957 \\ Family GLOBIGERINELLOIDIDAE Longoria, 1974 Genus BIGLOBIGERINELLA Lalicker, 1948 \\ Biglobigerinella $\mathrm{sp}$ \\ (Plate 1, Fig. 14)}

Remarks. Biglobigerinella is rare throughout the sections studied. The single specimen in Sample 120-747A-23X-1, 28-32 cm, may be a biapertural form of Globigerinelloides multispinatus, which is a dominant species. If so, it is more evolute with more globular, less appressed chambers than illustrated by Sliter (1977).

Genus GLOBIGERINELLOIDES Cushman and ten Dam, 1948

Globigerinelloides impensus Sliter, 1977

(Plate 1, Figs. 15-16)

Globigerinelloides impensus Sliter, 1977, p. 541, pl. 6, figs. 1-3.

Globigerinelloides impensus (Sliter) Huber, 1990, p. 503, pl. 1, figs. $10-11$.

Remarks. G. impensus is an important element of many of the faunas studied here and provides a useful opportunity to test its stratigraphic value (Huber, 1990). It seems to be one of the few stratigraphically significant species with an austral high-latitude dis- tribution. It normally has about eight chambers in the final whorl. The 10-chambered form illustrated by Sliter (1977) is exceedingly rare.

Care must be taken in differentiating this species from $G$. asperus asperus (Ehrenberg) as discussed by Belford (1981). The latter species has many discrete spines on all chambers excepting the last few, and these do not form nodes that are characteristic of $G$. impensus.

This species is akin to $G$. sp. 1 (see below) and has its inflated chambers. It is differentiated distinctly by the presence of rough nodes on the early chambers of the final whorl but lacks any development of a keel. It is also markedly compressed.

\section{Globigerinelloides multispinatus (Lalicker) , 1948}

(Plate 1, Figs. 17-18)

Biglobigerinella multispinatus Lalicker, 1948, p. 524, pl. 92, figs. 1-3. Globigerinelloides multispinatus (Lalicker) Huber, 1990, p. 503, pl. 1, figs. 11-12.

Remarks. As noted by Huber (1990), this is a very abundant form in the Maestrichtian. It commonly has 5 to $5 \frac{1}{2}$ chambers in the final whorl, but occasionally a population contains specimens with 6 , and individual specimens may be confused with G. alvarezi (Eternod Olvera). Rare small individuals may have as few as 4 chambers per whorl and are laterally similar to $G$. subcarinatus but differ in having inflated chambers.

\section{Globigerinelloides subcarinatus (Brönnimann), 1952}

(Plate 1, Fig. 20)

Globigerinella messinae subcarinata Brönnimann, 1952, p. 44, pl. 1, figs. 10-11; text-figs. 21a-m.

Globigerinelloides subcarinata (Brönnimann) Caron, 1985, p. 47, fig. $29,16-17$.

Globigerinelloides subcarinatus (Brönnimann) Huber, 1990, p. 503, pl. 1, fig. 14.

Remarks. This form is never abundant, but the numbers are enough in Hole $750 \mathrm{~A}$ samples to suggest that it becomes more compressed with time at this locality. This species may share a common ancestor with Globotruncanella petaloidea (Gandolfi), which has a similar time range and occasionally occurs in the same samples. As noted by Huber (1990), this species is restricted in southern high latitudes to the Maestrichtian.

\section{Globigerinelloides sp. 1}

(Plate 1, Fig. 22)

Remarks. This name is applied to a species with smooth test, inflated chambers, 7-8 per whorl, increasing slowly in size. The aperture is commonly bordered by a thin but marked lip. Relict apertures are commonly preserved. The degree of involution varies, and in some forms the final chamber or two are almost detached from the previous whorl. It is very similar to $G$. bentonensis (Morrow) but is much younger.

\section{Globigerinelloides $\mathrm{sp} .2$}

(Plate 1, Fig. 23)

Remarks. In this markedly compressed form that has 7-8 chambers in the final whorl, the last chambers may be smooth. The early chambers of the final whorl, however, have a distinct thin, transparent keel that may be continuous or in segments that join rough nodes developed on each chamber. Relict apertures are present but not well preserved.

This form is clearly closely related to $G$. impensus Sliter, but it has fewer chambers per whorl and is more compressed.

\section{Family SCHACKOINIDAE Pokorny, 1958}

Genus SCHACKOINA Thalmann, 1932

Caron (1985), as part of a comprehensive review of the Cretaceous planktonic foraminifers, recognized three species of Schackoina, none surviving into the Maestrichtian. This is in conflict with the evidence from this locality and other southern latitudes, where the genus is well known in the youngest Cretaceous.

Pessagno (1967) provided a comprehensive review of faunas over a much smaller region. Schackoina was a part of the faunas he studied. His comments on $S$. multispinata indicate a problem with this genus that calls for a thorough reevaluation of species concepts within it. Although not usually common, Schackoina is present sporadically 
almost worldwide in Late Cretaceous marine sediments. In the synonymy of $S$. multispinata given by Pessagno, there are five names recorded.

\section{Schackoina multispinata (Cushman and Wickenden), 1930}

$$
\text { (Plate 2, Figs. 1-2) }
$$

Hantkenina multispinata Cushman and Wickenden, 1930, p. 40, pl. 6, figs. 4-6.

Schackoina cenomana multispinata (Cushman and Wickenden) Bandy, 1967, p. 15 , text-fig. 6.

Schackoina multispinata (Cushman and Wickenden) Caron, 1985, p. 76 , fig. $35,10-13$.

Schackoina multispinata (Cushman and Wickenden) Huber, 1990, p. 503 , pl. 2, fig. 1.

Remarks. This name is applied in the sense defined by Caron (1985) as a species with about three chambers in the final whorl. The degree of variation on that theme is very great even though specimens are rare.

In this study, forms with more than one spine per chamber are very rare. A feature of this form is that the spines are more clearly differentiated from the chamber than is the case for $S$. cenomana. The two "species" are so similar that there may be a case for using the approach favored by Bandy (1967) and regarding $S$. multispinata as a subspecies of $S$. cenomana (Schacko).

\section{Schackoina sp.}

(Plate 2, Fig. 3)

Schackoina cenomana (Schacko) Quilty, 1973, p. 363, pl. 1, fig. 6. Schackoina sp. Belford, 1981, p. 51, pl. A6, figs. 23-26, esp. fig. 25.

Remarks. A single specimen from Sample 120-750A-16R-4, $28-32 \mathrm{~cm}$, seems to be a Globigerinelloides subcarinatus with a single spine on the ultimate chamber. It has four chambers in the final whorl and thus strictly should not be placed in $S$. multispinata. It is perhaps a less mature specimen of the species figured and discussed by Belford (1981). It is identical with the species figured by Quilty (1973) if the last chamber of that specimen were to be omitted.

\section{Superfamily ROTALIPORACEA Sigal, 1958}

Family HEDBERGELLIDAE Loeblich and Tappan, 1961 Genus HEDBERGELLA Brönnimann and Brown, 1958

Hedbergella amabilis Loeblich and Tappan, 1961 (Plate 2, Fig. 4)

Hedbergella amabilis Loeblich and Tappan, 1961, p. 274. pl. 3, figs. 1-10.

Hedbergella amabilis (Loeblich and Tappan) Pessagno, 1967, p. 281, pl. 52, figs. 6-8.

Hedbergella amabilis (Loeblich and Tappan) Eicher and Worstell, 1970 , p. 300 , pl. 9 , figs. 6,7 , and $9 a-c$.

Hedbergella amabilis (Loeblich and Tappan) Barr, 1972, p. 13, pl. 2, figs. $3 a-c$.

Hedbergella amabilis (Loeblich and Tappan) Quilty, 1973, p. 363, pl. 1 , fig. 9.

Hedbergella simplex (Morrow) (part) Caron, 1985, p. 59, fig. 25, $15-16$.

Remarks. The concept employed here is of a species with a chamber arrangement as illustrated by Pessagno (1967) and Eicher and Worstell (1970). A characteristic feature of the specimens recorded here is the presence, on the periphery, of spine bases and nodes that are consistent with a position intermediate between Hedbergella and Praeglobotruncana.

\section{Hedbergella holmdelensis Olsson, 1964} (Plate 2, Fig. 5)

Hedbergella holmdelensis Olsson, 1964, p. 160, pl. 1, figs. 1-2 Hedbergella holmdelensis (Olsson) Huber, 1990, p. 503, pl. 2, figs. $2-4$.

Remarks. Huber's concept of this species is employed here, that is, a species with slightly compressed chambers, in contrast with the usage by Caron (1985), which was of a species with inflated chambers. It is a rare form.

\section{Hedbergella aff. monmouthensis (Olsson), 1960}

(Plate 2, Figs. 6-8)

Hedbergella monmouthensis Olsson, 1960, p. 74, pl. 9, figs. 22-24 (in part).

Hedbergella monmouthensis (Olsson) Quilty, 1979, p. 118, pl. 1, figs. $7-8$.

Hedbergella monmouthensis (Olsson) Sliter, 1977, p. 542, pl. 3, figs. 1-3. Hedbergella monmouthensis (Olsson) Belford, 1981, p. 51, pl. A6, figs. 10-15.

Remarks. This is the dominant species of Hedbergella in the Campanian/Maestrichtian on the Southern Kerguelen Plateau. It is not $H$. monmouthensis in the sense of Huber (1990) as it generally has too high a trochospiral coil and a high proportion of the population has only 4 to $4 \frac{1}{2}$ chambers in the final whorl. The aperture normally faces into the umbilicus and often has a marked lip that is very variable in character. Huber (1990) figured H. monmouthensis, which does occur as part of the range of variation of this species and occasional entire populations, can be allocated to Huber's concept. The specimens are clearly part of one population in any sample, and it is equally clear that this important form must be understood in terms of its total variation. Figured specimens show that variation.

Huber (1990) placed Sliter's (1977) concept of this species within his Archaeoglobigerina australis, which is a species recognized as important in the faunas of the Southern Kerguelen Plateau. Its definition has been a major step in clarifying the nomenclature of austral high-latitude faunas, but I believe that the concept employed by Huber is too all-embracing in relation to small specimens. Thus I recognize this species of Hedbergella, but its nomenclature still is in need of clarification.

Belford (1981) figured as $H$. monmouthensis a form from offshore northwestern Australia. It seems indistinguishable from the species recorded here. There may be a difference between dominant populations at this time in the Atlantic and Indian oceans.

\section{Hedbergella sliteri Huber, 1990}

(Plate 2, Figs. 9-10)

Hedbergella sliteri Huber, 1990, p. 504, pl. 2, figs. 5, 9, and 10.

Remarks. The specimens recovered here have better developed portici than Huber's (1990) description would suggest. It is a common but never dominant form. The characters of the portici are more variable than indicated in Huber's description, and specimens vary from those with very narrow to those with flaplike but regular portici.

Hedbergella sp. 1

(Plate 2, Figs. 11-12)

Remarks. This is a very characteristic form, moderately large, somewhat compressed, almost planispiral. The rate of increase of chamber size is low, and the test is quite evolute dorsally. The aperture extends from the umbilicus as a low arch to the periphery, either with a single porticus, or with the aperture divided into peripheral and umbilical portions by a part of the porticus being in contact with the previous whorl.

\section{Genus WHITEINELLA Pessagno, 1967}

Remarks. Whiteinella is well represented in the poor quality samples in the lower parts of the section in Cores 120-750B-10W and $-11 W$. Statistics are virtually meaningless for the planktonic fauna at this level, but the genus is important and three species-W. archaeocretacea Pessagno, W. baltica Douglas and Rankin, and W. inornata (Bolli) - have been tentatively identified. Diagnostic features are not well preserved, but enough specimens were recovered that diagnostic features can be identified in a population.

Whiteinella archaeocretacea Pessagno, 1967

(Plate 2, Figs. 13 and 14)

Whiteinella archaeocretacea Pessagno, 1967, p. 298, pl. 51, figs. 2- 4; pl. 54 , figs. $19-25$; pl. 100 , fig. 8 .

Whiteinella archaeocretacea (Pessagno) Caron, 1985, p. 79, fig. 37, 4-5.

Remarks. Caron presented criteria for the differentiation of the species within this genus and, among them, used the characters of the periphery to separate $W$. archaeocretacea from $W$. inornata. In addition to this feature, it should be noted that commonly $W$. archaeocretacea 
has more than four chambers in the final whorl and, although not an absolute criterion, it is a valuable accessory criterion for differentiation.

Genus PRAEGLOBOTRUNCANA Bermudez, 1952

Praeglobotruncana delrioensis (Plummer) , 1931

(Plate 2, Figs. 19-21)

Globorotalia delrioensis Plummer, 1931, p. 199, pl. 13, fig. 2.

Praeglobotruncana delrioensis (Plummer) Herb, 1974, p. 752, pl. 3, fig. 14; figs. 5-6.

Praeglobotruncana delrioensis (Plummer) Sliter, 1977, pl. 8, figs. 1-3 and 6.

Remarks. This species is the key to the identification of Cenomanian marine sediments at Site 750. It is not known from a firm in situ sample but from a sweep sample from dark mud adhering to the lowest hard core sample above the nonmarine sediments of Cores 120-750B-12W and $-13 \mathrm{~W}$. The specimens of this species are rare indeed but well preserved even if, as in one case, fragmented. The source depth in the hole is not known but, as indicated by the presence of Whiteinella in Core 120 750B-10W, Cenomanian/Turonian marine sediments exist somewhere in the stratigraphic vicinity. The few specimens seen are typical.

A few very poorly preserved specimens obtained from the hard sample in Core 120-750B-11W, light lithology, are tentatively placed here even though the diagnostic features of the species are not wholly preserved. These are taken as $P$. cf. delrioensis (Plate 3, Figs. 1-2).

Genus CONCAVATOTRUNCANA Korchagin, 1982

Loeblich and Tappan (1988) pointed out that Dicarinella Porthault is not available until the position of the type species is clarified. Species previously placed in Dicarinella are routinely placed here.

\section{Concavatotruncana algeriana (Caron) 1966}

(Plate 3, Figs. 3-5)

Praeglobotruncana algeriana Caron, 1966, p. 74 (for illustration, see Reichel, 1950, pl. 16, fig. 8; pl. 17, fig. 8.

Dicarinella algeriana (Caron) Caron, 1985, p. 43, fig. 17, 1-2.

Remarks. Those rare, poorly preserved forms in Sample 120-750B$11 \mathrm{~W}, 128-130 \mathrm{~cm}$, identified as $C$. algeriana have the characteristics of the species as outlined by Caron (1985), that is, they have two rows of pustules weakly mimicking a double keel, and they have a broad, flat area between perpendicular to the equatorial surface. The dorsal surface lacks central pustules along the sutures; thus, the dorsal appearance is more reminiscent of Praeglobotruncana delrioensis. The double pustulose "keels" are imbricate in many specimens.

This is a key species in the identification of the Turonian section at Site 750B.

As noted in the introduction, there are specimens in samples from Core $120-747 \mathrm{C}-10 \mathrm{R}$ that are specifically unidentifiable. However, these samples do belong to a group of conical species that include $C$. algeriana, C. imbricata, and Praeglobotruncana, which are more consistent with an age older than the calcareous-nannoplankton-based lower Santonian.

\section{Concavatotruncana canaliculata (Reuss) 1854}

(Plate 3, Figs. 6-8)

Rosalina canaliculata Reuss, 1854 , p. 70 , pl. 26, figs. 4a-b.

Marginotruncana canaliculata (Reuss) Pessagno, 1967, p. 303, pl. 74, figs. 5-8.

Dicarinella canaliculata (Reuss) Caron, 1985, p. 43, fig. 17, 5-6.

Remarks. In Sample 120-750B-9W-2, $37-39 \mathrm{~cm}$, there is tentative identification of a species related to $C$. imbricata (Mornod) or C. canaliculata. The ventral details, however, are not fully visible. The margin is imbricate, but the keels are wider apart than normal for $C$. imbricata.

The identification from Sample 120-747C-10R-CC seems more positive and is used as the basis for the Santonian age designation.

\section{Concavatotruncana imbricata (Mornod) , 1950}

(Plate 3, Figs. 9-10)

Globotruncana imbricata Mornod, 1950, p. 589, fig. 5, IIIa-d.

Marginotruncana imbricata (Mornod) Pessagno, 1967, p. 306, pl. 57, figs. 3-5.

Dicarinella imbricata (Mornod) Caron, 1985, p. 45, fig. 18, 4-5.
Remarks. This species is poorly preserved and rare in the lower section at Site 750. It is an important element in the identification of the Turonian.

\section{Genus HELVETOGLOBOTRUNCANA Reiss, 1957}

\section{Helvetoglobotruncana sp. \\ (Plate 3, Figs. 11-12)}

Remarks. A few very poorly preserved specimens from the lower samples from Core 120-750B-11W are placed here. They have the flattened ventral surface of Helvetoglobotruncana and seem to have a single poorly developed keel around the early whorls. The keel is lacking from the last whorl, and the ultimate chamber is displaced ventrally from its expected position. These features are consistent with a position close to $H$. praehelvetica (Trujillo), but the material is too poor to have any confidence in a positive identification. The stratigraphic position, based on the accompanying fauna also is consistent with an identification as $H$. praehelvetica.

\section{Superfamily GLOBOTRUNCANACEA Brotzen, 1942 Family GLOBOTRUNCANIDAE Brotzen, 1942 Genus GLOBOTRUNCANA Cushman, 1927}

\section{Globotruncana falsostuarti Sigal, 1952}

(Plate 4, Figs. 1-2)

Globotruncana falsostuarti Sigal, 1952, p. 43, text-fig. 46. Globotruncana stuarti (de Lapparent) Pessagno, 1967, p. 357. Globotruncana falsostuarti (Sigal) Caron, 1985, p. 50, fig. 19, 10.

Remarks. There is a dispute over whether or not this is a distinct species or a variant of $G$. stuarti as suggested by Pessagno (1967). The material found here is not appropriate to the debate, and I have followed Caron (1985) in regarding it as a distinct species.

\section{Globotruncana linneiana (d’Orbigny) 1839}

(Plate 4, Figs. 3-5)

Rosalina linneiana d'Orbigny, 1839, p. 101, pl. 15, figs. 10-12.

Globotruncana linneiana (d'Orbigny) Brönnimann and Brown, 1956, p. 542 , pl. 20 , figs. $13-15$.

Globotruncana linneiana (d'Orbigny) Caron, 1985, p. 50, fig. 20, 5-6.

Remarks. Some of the specimens recovered from the interval low in the section at Hole 750B are quite well preserved, and there is little doubt about their identity. They seem stratigraphically out of place unless there is reworking that has not yet been recognized in the section.

\section{Globotruncana spp.}

Remarks. In Sample 120-750B-11W-CC, there are many poorly preserved specimens, especially with regard to their ventral features. Concavatotruncana imbricata has been identified but other species are present, possibly including $M$. pseudolinneiana and $M$. marginata. The latter identification is tentative, however.

\section{Genus MARGINOTRUNCANA Hofker, 1956}

Marginotruncana stephensoni (Pessagno) 1967 (Plate 4, Figs. 8-9)

Globotruncana stephensoni Pessagno, 1967, p. 354, pl. 69, figs. 1-7; pl. 96, figs. 5-6.

Remarks. I have taken $M$. stephensoni to be a separate, valid species rather than follow Caron's (1985) suggestion that it is a synonym of Globotruncana falsostuarti Sigal.

A single, very well-preserved specimen was recovered from Sample 120-750A-20R-CC. Although not identified through thin sectioning as advised by Pessagno (1967), the specimen has all the obvious features of the species and the age is consistent with the identification. The specimen has pustules on both ventral and dorsal surfaces, a feature not recorded by Pessagno.

\section{Marginotruncana sp.}

Remarks. In Sample 120-750B-10W-2, $128-130 \mathrm{~cm}$, there are several specimens of Marginotruncana that cannot be positively assigned to particular species within that genus. They have characteristics approximating those of several species. Normal variation 
within the species is low but there are a few marked oddities. It is characterized by a low domed dorsal surface with $51 / 2$ to 6 chambers in the final whorl. The dorsal keel is visible on all chambers and, although never very strongly pustulose, is less so in the latter few chambers. The dorsal chamber walls are flat.

The closest species seems to be $M$. marginata (Reuss), but the form recorded here lacks inflated chambers, may have too few chambers in the final whorl, and has "horseshoe shaped ventral sutures" (Bandy, 1967).

Other similar species include Globotruncana linneiana (d'Orbigny), from which it differs in age and in characters of the umbilical region. M. pseudolinneiana Pessagno is very similar, the only obvious difference being that this species is domed dorsally whereas $M$. pseudolinneiana is flat there. Perhaps $M$. sp is ancestral to $M$. pseudolinneiana.

\section{Genus RUGOTRUNCANA Brönnimann and Brown, 1956}

\section{Rugotruncana circumnodifer (Finlay) , 1940}

(Plate 4, Figs. 14-15)

Globotruncana circumnodifer Finlay, 1940, p. 469, pl. 65, figs. 150-157. Globotruncana (Rugotruncana) circumnodifer (Finlay) Webb, 1973, p. 552 , pl. 4 , figs. 1-4.

Rugotruncana circumnodifer (Finlay) Huber, 1990, p. 505, pl. 4, figs. 4-10.

Remarks. This is the same form as identified by Huber (1990), but the tegillae are very rare. It occurs in the $A$. mayaroensis Zone.

\section{Rugotruncana subpennyi (Gandolfi) 1955}

(Plate 4, Figs. 12-13)

Globotruncana (Rugoglobigerina) pennyi subpennyi Gandolfi, 1955 , p. 73 , pl. 7 , figs. $7 \mathrm{a}-\mathrm{c}$.

Rugotruncana subpennyi (Gandolf), Caron, 1985, p. 76, fig. 34, 13-14.

Remarks. Two species from the lower Maestrichtian at Site 750 are included here. One is $R$. subpennyi sensu stricto. The other is very closely related and seems to be between $R$. subpennyi and $R$. subcircumnodifer (Gandolfi). Both are figured, the latter as $R$. aff. subpennyi (Plate 4, Figs. 10 and 11). It has only a single keel, which is imbricate to a greater extent than is typical for $R$. subpennyi, and the test surface is marked by better developed rugosities. Another very similar species, but one lacking keels altogether, is Rugoglobigerina rugosa (Plummer).

Neither species is common and they may be variants of a population that is not well enough represented to show the intergradation.

\section{Genus GLOBOTRUNCANELLA Reiss, 1957}

Globotruncanella citae (Bolli), 1951

(Plate 4, Figs. 6 and 17)

Globotruncana citae Bolli, 1951, p. 197, pl. 35, figs. 4-6.

Globotruncanella citae (Bolli) Caron, 1985, p. 51, fig. 21, 1-2.

Remarks. Those specimens from the youngest Maestrichtian section in Hole $750 \mathrm{~A}$ commonly have weakly developed second keels on the umbilical side of the test. This does not alter the overall shape of the test, perhaps consistent with its role as the progenitor of Abathomphalus mayaroensis.

\section{Genus ABATHOMPHALUS Bolli, Loeblich and Tappan 1957}

Differentiation of $A$. intermedius (Bolli) and A. mayaroensis (Bolli)

Various authors have used a variety of criteria for differentiating these important upper Maestrichtian species. Applying most criteria to the Kerguelen Plateau material gave a confused result. The only criterion that proved consistently satisfactory was the degree to which the keels are composed of radially elongate costellae. Of course, this feature also intergrades, but it seems capable of consistent application.

Family RUGOGLOBIGERINIDAE Subbotina, 1959

Genus ARCHAEOGLOBIGERINA Pessagno, 1967

\section{Archaeoglobigerina aff. blowi Pessagno, 1967} (Plate 5, Figs. 9-10)

Remarks. Sample 120-750A-21R-1, 28-32 cm, yielded several specimens of an unidentifiable species, referred here to Archaeoglobigerina and, for comparison, related to $A$. blowi. The form has three chambers in the final whorl, the ultimate composing about $50 \%$ of the test volume. The chambers increase rapidly in size and have an essentially smooth surface. The form has an aperture with a narrow but prominent porticus. There is no obvious imperforate peripheral band.

If only a single specimen occurred, one would regard it as an unusual variant of another species of Archaeoglobigerina; however, because so many specimens are present, it is here taken as a species proper. It could be developed from $A$. blowi by an increase in the rate of chamber size from the form of $A$. blowi figured by Caron $(1985$, fig. 16, 4).

\section{Archaeoglobigerina bosquensis Pessagno, 1967} (Plate 5, Fig. 11)

Archaeoglobigerina bosquensis Pessagno, 1967, p. 316, pl. 60, figs. 10-12.

Archaeoglobigerina bosquensis (Pessagno) Caron, 1985, p. 43, fig. 16, 5-6.

Remarks. A single specimen occurs in Sample 120-750B-10W-1, 60 $\mathrm{cm}$, which can be used to suggest that the section in that hole at this stratigraphic level is not older than Coniacian.

A single specimen from Sample $120-750 \mathrm{~A}-18 \mathrm{R}-\mathrm{CC}$ is referred to as $A$. aff. bosquensis. It is a large specimen with 6 chambers in the final whorl. The chamber surface is essentially smooth on the final whorl that is hispid on earlier chambers. There is a pair of rows of faint concentrations of hispidity. This becomes fainter with age. The specimen occurs in sediments far too young for $A$. bosquensis.

\section{Archaeoglobigerina sp. \\ (Plate 5, Figs. 13-14)}

Remarks. In Hole $747 \mathrm{C}$, below the horizon at which A. australis has its FAD, there is a species difficult to classify as well as to identify. It is a high-spired archaeoglobigerinid in most features, but there is a moderate proportion of specimens with simple dorsal supplementary apertures. The supplementary apertures have no rim or lip. The spire height of the population varies considerably. The ventral apertures are as for Archaeoglobigerina, either simple or with portici that are prominent and narrow projections when present.

Pessagno (1967) defined Loeblichella to include species with the characters outlined for the species recorded here, although this species cannot be identified as either of the forms recognized by Pessagno. Loeblich and Tappan (1988) placed Loeblichella in their category of "Genera of uncertain affinity" because of the statement by Masters (1977) that Loeblichella hessi (Pessagno) used as the type of the genus is an internal mold and that the sutural supplementary apertures do not exist. The material described here is does not consist of internal molds. Thus, the features used to define the genus exist, although they appear to be developed only in part of a population, not in all its members. The problem remains unresolved.

\section{Genus RUGOGLOBIGERINA Brönnimann, 1952 \\ Rugoglobigerina reicheli Brönnimann, 1952 (Plate 5, Figs. 15-16)}

Rugoglobigerina reicheli reicheli Brönnimann, 1952, p. 18, pl. 3, figs. $10-12$.

Rugoglobigerina reicheli reicheli (Brönnimann) Bolli et al., 1957, p. 43. Rugoglobigerina reicheli (Brönnimann) Pessagno, 1967, p. 365, pl. 65, figs. 5-7.

Rugoglobigerina reicheli (Brönnimann) Caron, 1985, p. 72, fig. 34, 5-6.

Remarks. A few poorly preserved specimens from the upper Maestrichtian at Site 750 are recorded here. Their test form is consistent with either Rugoglobigerina reicheli or with the holotype of $R$. scotti as illustrated by Bolli et al. (1957), taken to be a better illustration of that holotype than the figures of Caron (1985). The specimen illustrated here appears to have abraded rugosities. What remains suggests a very coarse surface indeed.

\section{Rugoglobigerina aff. rugosa (Plummer) , 1927} (Plate 5, Figs. 17-18)

Rugoglobigerina rugosa (Plummer) Edgell, 1957, p. 115, pl. 4, figs. $10-12$.

Remarks. The few specimens in Sample 120-750A-15R-CC are of a form with rugosities showing little alignment, certainly not enough 
to identify the species firmly as $R$. rugosa. There is a well-developed tegilla but no evidence of a keel. This is clearly the species recorded by Edgell (1957) from rocks of essentially the same age.

Other specimens in the same section referred to this species are non-tegillate although a few specimens show traces. Without the occurrence of the tegillate form at the top of the section, it would seem logical to regard all as Archaeoglobigerina and as descended from $A$. australis Huber by development of nodes that sometimes have some alignment. In some samples, the species is quite common and very well preserved.

\section{Rugoglobigerina tradinghousensis Pessagno, 1967} (Plate 5, Fig. 19)

Rugoglobigerina tradinghousensis Pessagno, 1967, p. 367, pl. 64, figs. $1-8$.

Remarks. A few typical specimens occur in Sample 120-747A$24 \mathrm{X}-3,26-30 \mathrm{~cm}$. They have 4 chambers in the final whorl. As shown on the figured specimen, apertural lips are extended almost across the aperture but do not unite to form a tegillum. The form of the extended lip is variable. This feature seems to be as in the figures of the type specimens (Pessagno, 1967). Rugosities are present on the dorsal surface of early chambers, but they are absent from the last whorl, although there is some alignment of surface features at the finer level even on the last few chambers.

\section{SPECIES RECORDED WITHOUT COMMENT}

Abathomphalus intermedius (Bolli) $=$ Globotruncana intermedia Bolli, 1951, p. 197, pl. 35, figs. 7-9

Abathomphalus mayaroensis $($ Bolli) $=$ Globotruncana mayaroensis Bolli, 1951, p. 190 , pl. 35, figs. 10-12

Archaeoglobigerina australis Huber, 1990, p. 504, pl. 1, figs. 9-12; pl. 2, fig. 1

Archaeoglobigerina aff. bosquensis Pessagno

Archaeoglobigerina pilula (Belford) = Rugoglobigerina pilula Belford, 1960 , p. 92 , pl. 25 , figs. 7-13

Archaeoglobigerina sp. 1

Contusotruncana fornicata (Plummer) = Globotruncana fornicata Plummer, 1931, p. 130 , pl. 13 , figs. $4 a-c$

Globigerinelloides prairiehillensis Pessagno, 1967, p. 277, pl. 60, figs. 2 and 3 ; pl. 83 , fig. 1 ; pl. 90 , figs. 1,2 , and 4 ; pl. 97 , figs. 3 and 4 Globigerinelloides ultramicra $($ Subbotina $)=$ Globigerinella ultramicra Subbotina, 1949, p. 33, pl. 2, figs. 17 and 18

Globotruncana arca $($ Cushman) = Pulvinulina arca Cushman, 1926, p. 23 , pl. 3 , figs. la $-\mathrm{c}$

Globotruncana bulloides Vogler = Globotruncana linnei (d'Orbigny), var. bulloides Vogler, 1941, p. 231, pl. 23, figs. 32-39

Globotruncana globigerinoides Brotzen, 1936, p. 177, pl. 12, figs. 3a-c; pl. 13, fig. 3

Globotruncana sp. indet.

Globotruncanella havanensis (Voorwijk) = Globotruncana havanensis Voorwijk, 1937, p. 195, pl. 1, figs. 25, 26, and 29

Globotruncanella petaloidea $($ Gandolfi) $=$ Globotruncana $($ Rugoglobigerina) petaloidea subsp. petaloidea Gandolfi, 1955, p. 52, pl. 3, figs. $13 \mathrm{a}-\mathrm{c}$

Globotruncanids indet.

Guembelitria cretacea Cushman, 1933, p. 37, pl. 4, fig. 12

Hastigerinoides subdigitata $($ Carman $)=$ Globigerina subdigitata Carman, 1929 , p. 315 , pl. 34 , figs. 4 and 5

Hedbergella spp. indet.

Pseudotextularia deformis (Kikoine) $1948=$ Guembelina striata (Ehrenberg) var. deformis Kikoine, 1948, p. 20, pl. 1, figs 8a-c

Rugoglobigerina sp. 1

Rugoglobigerina sp.

Rugotruncana aff. subpennyi (Gandolfi)

Whiteinella baltica Douglas and Rankin, 1969, p. 198, text-figs. 9A-C

Whiteinella inornata $($ Bolli) $=$ Globotruncana inornata Bolli, 1957, p. 57 , pl. 13 , figs. $5 \mathrm{a}-\mathrm{c}$

\section{SUMMARY AND CONCLUSIONS}

Planktonic foraminifers are identified, figured, and, where appropriate, discussed from Upper Cretaceous sections at three sites $(747,748$, and 750 ) drilled by Leg 120 on the
Southern Kerguelen Plateau, Indian Ocean. The interval studied is upper Cenomanian to upper Maestrichtian inclusive, although in sections older than upper Campanian control is poor and both sample and time coverage patchy.

Faunal diversity, structure, and morphological features of the species (such as presence or absence of keels, complexity of biserial forms) have been used to deduce temperature and temperature change for the time interval studied. Some of the results have been incorporated in the paper by Quilty (Chapter 23 , this volume) on benthic foraminifers, and that paper also includes reference to the sampling and processing methods employed.

The Cretaceous at Site 747 extends from $189.5 \mathrm{mbsf}$ (between Samples 120-747C-3R-3, 42-43 cm, and -3R-3, $52-53 \mathrm{~cm}$ ) to $295.1 \mathrm{mbsf}$ (Sample 120-747C-10R-CC). This conclusion is slightly at variance with that of Aubry and Berggren (1989), who placed the Cretaceous/Tertiary transition between Cores 120-747C-3R and -4R, a difference of some tens of centimeters. The stratigraphic subdivision of the interval is as follows:

1. upper Maestrichtian G. gansseri Zone (191.65-213.28 mbsf), including Samples 120-747A-21X-2, 60-62 cm, and $-23 \mathrm{X}-4,28-32 \mathrm{~cm}$;

2. lower Maestrichtian, undifferentiated (214.78-227.78 mbsf), including Samples 120-747A-23X-5, 28-32 cm, and $-25 \mathrm{X}-1,28-32 \mathrm{~cm}$;

3. upper Campanian G. impensus Zone (229.28-290.4 mbsf), including Samples 120-747A-25X-2, 28-32 cm, and 120-747C-10R-1, 40-43 cm; and

4. lower Santonian or older, undifferentiated (295.1 mbsf), Sample 120-747C-10R-CC.

The Cretaceous/Tertiary contact is unconformable and within a complex volcaniclastic debris-flow sequence. The Campanian/Santonian boundary is also thought to be unconformable. Below the Santonian, drilling entered basalt.

Faunas can be allocated as follows:

1. Santonian-Transitional;

2. Campanian-lower Maestrichtian and much of the upper Maestrichtian-Austral; and

3. uppermost Maestrichtian-Transitional, representing the warmer part of the TFP.

Planktonic foraminifer faunas at Site 748 are minor, from very shallow marine conditions and they provided little stratigraphic or faunal province information. Control for the sequence at Site 748 is based on other microfossil groups.

The section at Site 750 was poorly sampled, and the boundaries between various stratigraphic units are poorly defined in both time and sample terms.

The stratigraphic section, to the extent decipherable, is

1. upper Cenomanian: identified by key species from the dark, soft mud adhering to Core $120-750 \mathrm{~B}-11 \mathrm{~W}-2$; source unknown;

2. Turonian: as above, source unknown;

3. upper Campanian $G$. impensus Zone: lower boundary very poorly defined but with the upper limit at $450.18 \mathrm{mbsf}$ (Sample $120-750 \mathrm{~B}-3 \mathrm{R}-1,18 \mathrm{~cm}$ ), which is the LAD of $G$. impensus;

4. lower Maestrichtian, undifferentiated: from the LAD of Globigerinelloides impensus at 450.18 mbsf (Sample 120$750 \mathrm{~B}-3 \mathrm{R}-1,18 \mathrm{~cm}$ ) to the FAD of Globotruncanella citae at 413.6 mbsf (Sample 120-750A-21R-CC);

5. upper Maestrichtian $G$. gansseri Zone: from the FAD of Abathomphalus intermedius at 394.9 mbsf (Sample 120-750A- 
20R-1, 50-54 cm) to Sample 120-750R-19R-1, 28-32 cm ( $384.98 \mathrm{mbsf}$ ) immediately below the FAD of $A$. mayaroensis;

6. upper Maestrichtian A. mayaroensis Zone: from the FAD of A. mayaroensis at 384.7 mbsf (Sample 120-750R-18R$\mathrm{CC})$ to the unconformable Cretaceous/Tertiary contact at 355.8 mbsf (Sample 120-750A-15R-CC).

The faunal structure suggests that water temperature may have been higher at this site than at Site 747 even though this site is farther south, possibly indicating the presence of a counterclockwise gyre to the east of Kerguelen Plateau that would cause Site 750 to receive warm water from the eastern gyre while bathing Site 747 in cooler water from a more westerly gyre.

\section{ACKNOWLEDGMENTS}

I thank my daughter Marian for her assistance in so many facets of the tedious work of preparing and assembling the plates; Bob Reeves of the Australian Antarctic Division (AAD) for his continuing aid with photography; Andrew McEldowney and Geraldine Nash (AAD) for help with electron microscopy; Pat Waddington (AAD) for all the diverse support at the office; and the shipboard company who made the whole thing a great experience.

\section{REFERENCES}

Aubry, M.-P., and Berggren, W. A., 1989. Age of the upper volcaniclastic debris flow at Site 747: a special study. In Schlich, R., Wise, S. W., Jr., et al., Proc. ODP, Init. Repts., 120: College Station, TX (Ocean Drilling Program), 57-69.

Bandy, O. L., 1967. Cretaceous planktonic foraminiferal zonation. Micropaleontology, 13:1-31.

Barr, F. T., 1972. Cretaceous biostratigraphy and planktonic foraminifera of Libya. Micropaleontology, 18:1-46.

Bassias, Y., Davies, H. L., Leclaire, L., and Weis, D., 1987. Basaltic basement and sedimentary rocks from the southern sector of the Kerguelen-Heard Plateau: new data and their Meso-Cenozoic paleogeographic and geodynamic implication. Bull. Mus. Natl. Hist. Nat., Sect. C, 4:367-403.

Belford, D. J., 1960. Upper Cretaceous foraminifera from the Toolonga Calcilutite and Gingin Chalk, Western Australia. Bull. Bur. Miner. Resour., Geol. Geophys. Aust., 57:1-198.

1981. Late Cretaceous planktic foraminifera in Valdivia Core KL1 from the Scott Plateau, off northwestern Australia. Bull. Bur. Miner. Resour. Geol. Geophys. Aust., 213:48-67.

Bolli, H. M., 1951. The genus Globotruncana in Trinidad, B.W.I. J. Paleontol., 25:187-197.

Bolli, H. M., Loeblich, A. R., Jr., and Tappan, H., 1957. Planktonic foraminiferal Families Hantkeninidae, Orbulinidae, Globorotaliidae, and Globotruncanidae. Bull. U.S. Nat. Mus., 215:3-50.

Brönnimann, P., 1952. Globigerinidae from the Upper Cretaceous (Cenomanian-Maestrichtian) of Trinidad, B.W.I. Bull. Am. Paleontol., 34(140):1-70.

Brönnimann, P., and Brown, N. K., Jr., 1956. Taxonomy of the Globotruncanidae. Eclogae Geol. Helv., 48:503-561.

Brotzen, F., 1936. Foraminiferen aus dem Schwedischen untersten Senon von Eriksdal in Schonen. Arsb. Sver. Geol. Unders., Ser. C. 396:1-206.

Burckle, L. H., Saito, T., and Ewing, M., 1967. A Cretaceous (Turonian) core from the Naturaliste Plateau, southeast Indian Ocean. Deep Sea Res. Oceanogr. Abstr., 14:421-426.

Carman, K. W., 1929. Some foraminifera from the Niobrara and Benton Formations of Wyoming. J. Paleontol., 3:309-315.

Caron, M., 1966. Globotruncanidae du Crétacé supérieur du synclinal de la Gruyère (Préalpes médianes, Suisse). Rev. Micropaleontol., 2:68-93.

1985. Cretaceous planktonic foraminifera. In Bolli, H. M., Saunders, J. B., and Perch-Nielsen, K. (Eds.), Plankton Stratigraphy: Cambridge (Cambridge Univ. Press), 17-86.

Cushman, J. A., 1926. Some foraminifera from the Mendez Shale of eastern Mexico. Contrib. Cushman Lab. Foraminiferal Res., 2:16-26.
1933. Some new foraminiferal genera. Contrib. Cushman Lab. Foraminiferal Res., 9:32-38.

1938. Cretaceous species of Guembelina and related genera. Contrib. Cushman Lab. Foraminiferal Res., 14:2-28.

Cushman, J. A., and Wickenden, R. T., 1930. The development of Hantkenina in the Cretaceous with a description of a new species. Contrib. Cushman Lab. Foraminiferal Res., 6:39-43.

d'Orbigny, A., 1839. Foraminiferes. In de la Sagra, R. (Ed.), Histoire Physique Politique et Naturelle de l'île de Cuba: Paris (Bertrand).

Douglas, R. G., and Rankin, C., 1969. Cretaceous planktonic foraminifera from Bornholm and their zoogeographic significance. Lethaia, 2:185-217.

Edgell, H. S., 1957. The genus Globotruncana in northwest Australia. Micropaleontology, 3:101-126.

Egger, J. G., 1902. Foraminiferen und Ostrakoden aus den Kreidemergeln der Oberbayerischen Alpen. Abh. Bayer. Akad. Wiss. Math.-Naturwiss. Kl., 21:1-230.

Ehrenberg, C. G., 1839. Uber die Bildung der Kreidefelsen und des Kreidemergels durch unsichtbare Organismen. Abh. K. Akad. Wiss. Berlin (1838), 59-157.

Eicher, D. L., and Worstell, P., 1970. Cenomanian and Turonian foraminifera from the Great Plains, United States. Micropaleontology, 16:269-324.

Finlay, H. J., 1940. New Zealand Foraminifera: key species in stratigraphy. Trans. R. Soc. N. Z., 69:448-472.

Gandolfi, R., 1955. The genus Globotruncana in northeastern Colombia. Bull. Am. Paleontol., 36:1-118.

Herb, R., 1974. Cretaceous planktonic foraminifera from the eastern Indian Ocean. In Davies, T. A., Luyendyk, B. P., et al., Init. Repts. DSDP, 26: Washington (U.S. Govt. Printing Office), 745770 .

Herb, R., and Scheibnerova, V., 1977. Synopsis of Cretaceous planktonic foraminifera from the Indian Ocean. In Heirtzler, J. R., Bolli, H. M., Davies, T. A., Saunders, J. B., and Sclater, J. G. (Eds.), Indian Ocean Geology and Biostratigraphy: Washington (Am. Geophys. Union), 399-415.

Huber, B. T., 1988. Upper Campanian-Paleocene foraminifera from the James Ross Island region, Antarctic Peninsula. In Feldmann, R. M., and Woodburne, M. O. (Eds.), Geology and Paleontology of Seymour Island, Antarctica. Mem. Geol. Soc. Am., 169:163252.

1990. Maestrichtian planktonic foraminifer biostratigraphy of the Maud Rise (Weddell Sea, Antarctica): ODP Leg 113 Holes 689B and 690C. In Barker, P. F., Kennett, J. P., et al., Proc. ODP. Sci. Results, 113: College Station, TX (Ocean Drilling Program), 489-513.

1991a. Planktonic foraminifer biostratigraphy of Campanian-Maestrichtian sediments from Sites 698 and 700, southern Atlantic Ocean. In Ciesielski, P. F., Kristoffersen, Y., et al., Proc. $O D P$, Sci. Results, 114: College Station, TX (Ocean Drilling Program), 281-297.

1991b. Maestrichtian planktonic foraminifer biostratigraphy and the Cretaceous/Tertiary boundary at Hole $738 \mathrm{C}$, Kerguelen Plateau (southern Indian Ocean), In Barron, J., Larsen, B., et al., Proc. ODP, Sci. Results, 119: College Station, TX (Ocean Drilling Program), 451-466.

Kemp, E. M., and Harris, W. K., 1975. The vegetation of Tertiary islands on the Ninetyeast Ridge. Nature, 58:303-307.

Kikoine, J., 1948. Les Heterohelicidae du Cretace superieur pyreneen. Bull. Geol. Soc. Fr., Ser. 5, 18:15-35.

Lalicker, C. G., 1948. A new genus of foraminifera from the Upper Cretaceous. J. Paleontol., 22:624.

Loeblich, A. R., Jr., 1951. Coiling in the Heterohelicidae. Contrib. Cushman Found. Foraminiferal Res., 2:106-111.

Loeblich, A. R., Jr., and Tappan, H., 1961. Cretaceous planktonic foraminifera. Part 1. Cenomanian. Micropaleontology, 7:257-304. 1988. Foraminiferal Genera and their Classification: New York (Van Nostrand Reinhold).

McGowran, B., 1974. Foraminifera. In von der Borch, C. C., Slater, J. G., et al., Init. Repts. DSDP, 22: Washington (U.S. Govt. Printing Office), 609-627.

Masters, B. A., 1977. Mesozoic planktonic foraminifera, a world-wide review and analysis. In Ramsay, T. S. (Ed.), Oceanic Micropaleontology (Vol. 1): London (Academic Press), 301-731. 
Montanaro Gallitelli, E., 1957. A revision of the foraminiferal family Heterohelicidae. Bull. U.S. Nat. Mus., 215:133-154.

Mornod, H. L., 1950. Des Globorotalidés du Crétace supérieur du Montsalvens (Préalpes fribourgeoises). Eclogae Geol. Helv., 42:573-596.

Olsson, R., 1964. Late Cretaceous planktonic foraminifera from New Jersey and Delaware. Micropaleontology, 10:157-188.

Pessagno, E. A., 1967. Upper Cretaceous planktonic foraminifera from the western Gulf Coastal Plain. Palaeontogr. Am., 5:245445 .

Plummer, H. J., 1931. Some Cretaceous foraminifera in Texas. Bull. Univ. Texas, 3101:109-203.

Quilty, P. G., 1973. Cenomanian-Turonian and Neogene sediments from northeast of Kerguelen Ridge, Indian Ocean. J. Geol. Soc. Aust., 20:361-371.

1979. The Late Cretaceous-Tertiary section in Challenger No. 1 (Perth Basin): details and implications. Bull. Bur. Miner. Resour. Geol. Geophys. Aust., 192:109-135.

Reichel, M., 1950. Observations sur les Globotruncana du gisement de la Breggia (Tessin). Eclogae Geol. Helv., 42:596-617.

Reuss, A. E., 1854. Beiträge zur charakteristik der Kreideschichten in der Ostalpen, besonders im Gosauthale und am Wolfgangsee. Denkschr. Kais. Akad. Wiss. Math.-Naturwiss. Kl., 7:1-156.

Schlich, R., Wise, S. W., Jr., et al., 1988. That sinking feeling. Nature, 334:385-386.

1989. Proc. ODP, Init Repts., 120: College Station, TX (Ocean Drilling Program).

Sigal, J., 1952. Aperçu stratigraphique sur la micropaleontologie du Crétace. Monogr. Rég. Inter. Geol. Congr., 19th, Ser. I, 26:1-47.

Sliter, W. V., 1977. Cretaceous foraminifers from the southwestern Atlantic Ocean, Leg 36, Deep Sea Drilling Project. In Barker, P., Dalziel, I.W.D., et al., Init. Repts. DSDP, 36: Washington (U.S. Govt. Printing Office), 519-574.

Stenestad, E., 1968. Three new species of Heterohelix Ehrenberg from the Upper Senonian of Denmark. Bull. Geol. Soc. Den., 18:64-74.

Subbotina, N. N., 1949. Microfauna of the southern slope of the Caucasus (in Russian). Tr. Vses. Neftyanogo Nauchno-Issled. Geologo-razvedochnogo Inst., sbornik 2, new ser., 34:33.

Thierstein, H. R., Asaro, F., Ehrmann, W. U., Huber, B., Michel, H., Sakai, H., and Schmitz, B., 1991. The Cretaceous/Tertiary boundary at Site 738 , south Kerguelen Plateau. In Barron, J., Larsen, B., et al., Proc. ODP, Sci. Results, 119: College Station, TX (Ocean Drilling Program), 849-868.

Vogler, J., 1941. Ober-Jura und Kreide von Misol. In Boehm, G., and Wanner, J. (Eds.), Beitrage zur Geologie von NiederlandischIndian. Palaeontographica (Suppl.): 4:243-293.

Voorwijk, G. H., 1937. Foraminifera from the Upper Cretaceous of Habana, Cuba. Koninkl. Nederlandse Akad. Wetensch., Proc. Sec. Sci., 40:190-198.

Webb, P.-N., 1973. Upper Cretaceous-Paleocene foraminifera from Site 208 (Lord Howe Rise, Tasman Sea), DSDP, Leg 21. In Burns, R. E., Andrews, J. E., et al., Init. Repts. DSDP, 21: Washington (U.S. Govt. Printing Office), 541-573.

Date of initial receipt: 24 January 1990

Date of acceptance: 20 September 1990 120B-174

\section{APPENDIX}

\section{Cretaceous/Tertiary Contact at Site $\mathbf{7 4 7}$}

There is dispute concerning the nature of the contact between the Cretaceous and Tertiary. It is unconformable, the unconformity representing a time interval of $2-3 \mathrm{~m} . \mathrm{y}$. (Aubry and Berggren, 1989). The problem concerns differences of opinion about the interpretation of samples in the interval from Sections 120-747C-3R-2 to -3R-3 (Aubry and Berggren, 1989). For the purposes of this paper, the contact is placed between Samples $120-747 \mathrm{C}-3 \mathrm{R}-3,42-43 \mathrm{~cm}$, and $-3 \mathrm{R}-3,52-53 \mathrm{~cm}$. Thus, it is taken as being within Section 120-747C-3R-3 rather than between Cores $120-747 \mathrm{C}-3 \mathrm{R}$ and $-4 \mathrm{R}$, as suggested by
Aubry and Berggren (1989). The following comments on the samples examined are in support of the interpretation used here. The comments made during examination of the processed samples are augmented by notes made during sampling.

Sample 120-747C-3R-2, 86-87 cm, was taken in what appears to be a burrow, an oblique, oval structure. The sample consists of $80 \%-85 \%$ foraminifers and $15 \%-20 \%$ lithic fragments that are of red-brown and dark gray volcanic rocks, the former occasionally vesicular (or more properly amygdaloidal as the vesicles are filled with white-pale green "clay"). Neither volcanic type has any obvious internal structure other than crystallinity. Grains are angular to subrounded and range up to a little over $1 \mathrm{~mm}$ in diameter. The rest of the lithic component is of pale green, apparently amorphous material, very soft and clayey. There are rare quartz grains.

The foraminifer fauna consists dominantly of Tertiary species, but there is a significant Cretaceous component-up to $10 \%$ that is less well preserved than the Tertiary material and includes Inoceramus, Globigerinelloides, Hedbergella, Heterohelix and others, commonly pale yellow in color, suggesting a weathered source. Sample 120-747C-3R-2, 92-93 cm, represents the matrix surrounding the burrow and is much the same as the one above; however, the volcanic component is coarser grained on average. There are a few very wellpreserved Cretaceous forms that are preserved as well as those Tertiary species present.

Sample $120-747 \mathrm{C}-3 \mathrm{R}-3,13-14 \mathrm{~cm}$, is similar to those above. The volcanic particles are a little coarser grained and slightly more abundant. Cretaceous reworked material is poorly preserved.

Sample 120-747C-3R-3, 42-43 cm, differs strongly from those above. It consists dominantly of well-preserved Cretaceous forms with a minor admixture of Tertiary globigerinids. The volcanic component, although identical to that in the samples above, is generally finer grained and less well sorted.

Sample 120-747C-3R-3, 52-53 cm, represents a marked change from the samples above. Volcanic fragments make up $70 \%-80 \%$ and are dominated by a medium-gray form that occurs as grains up to $4-5 \mathrm{~mm}$ in diameter. Sorting of the volcanic component is very poor. There are absolutely clear euhedral zeolite(?) crystals present. Preservation of the carbonate component is poor but consists of Cretaceous forms only.

Sample $120-747$ C-3R-3, $85-86 \mathrm{~cm}$, is similar to the sample above but it has a higher carbonate content (almost $70 \%$ ). The characteristics of the volcanic fragments, zeolites, and carbonate grains are as above.

Sample $120-747$ C-3R-3, $106-107 \mathrm{~cm}$, is as above, but the volcanic content is higher, perhaps $60 \%$.

Sample $120-747$ C-3R-3, $138-139 \mathrm{~cm}$, is as above, but the volcanic and zeolite components are more prominent, with the volcanic component constituting $70 \%$.

Based on this examination, this section should be divided into three units:

1. The upper unit, including Samples 120-747C-3R-2, 86-87 $\mathrm{cm}$, to $-3 \mathrm{R}-3,13-14 \mathrm{~cm}$, is Tertiary with reworked Cretaceous and a characteristic volcanic component. This unit darkens 
down sequence and the proportion of ooze declines. Visually the base of this unit is placed at Sample 120-747C-3R-3, $23 \mathrm{~cm}$.

2. The middle unit is represented by the single sample at $120-747 \mathrm{C}-3 \mathrm{R}-3,42-43 \mathrm{~cm}$, and is Tertiary with reworked Cretaceous or Cretaceous with Tertiary bioturbated into it.

3. The lower unit is Cretaceous, or at least there is no evidence of Tertiary in it from this examination. It is charac- terized by poor preservation of the carbonate fraction (among which well-preserved Tertiary would stand out if present) and by its different volcanic and zeolite components. The top of this unit is placed between Samples 120-747C-3R-3, 42-43 $\mathrm{cm}$, and $120-747 \mathrm{C}-3 \mathrm{R}-3,52-53 \mathrm{~cm}$.

The interval is complex, dominated by what are interpreted as debris flows, found in the section as deep as $205 \mathrm{mbsf}$ in Maestrichtian sediments. The youngest debris flow is the controversial one (part of Unit III) at 180.9 mbsf. 


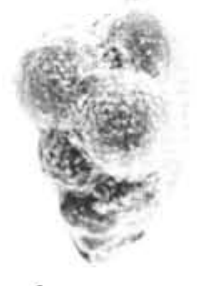

1

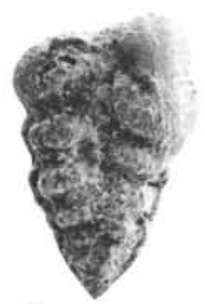

7

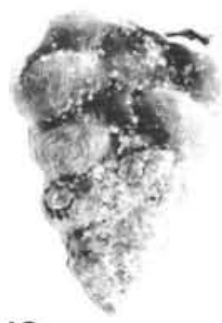

13

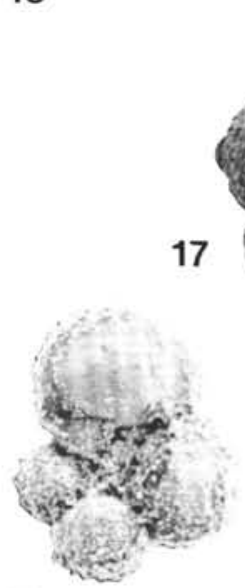

20
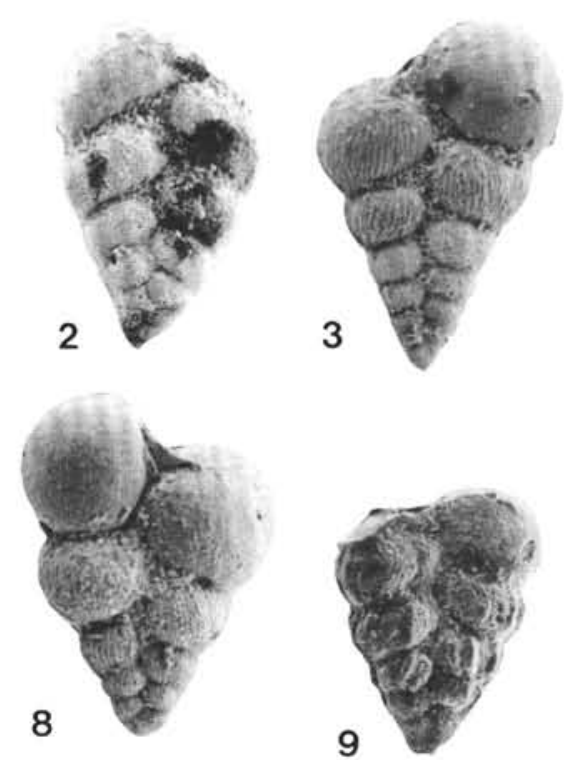

14
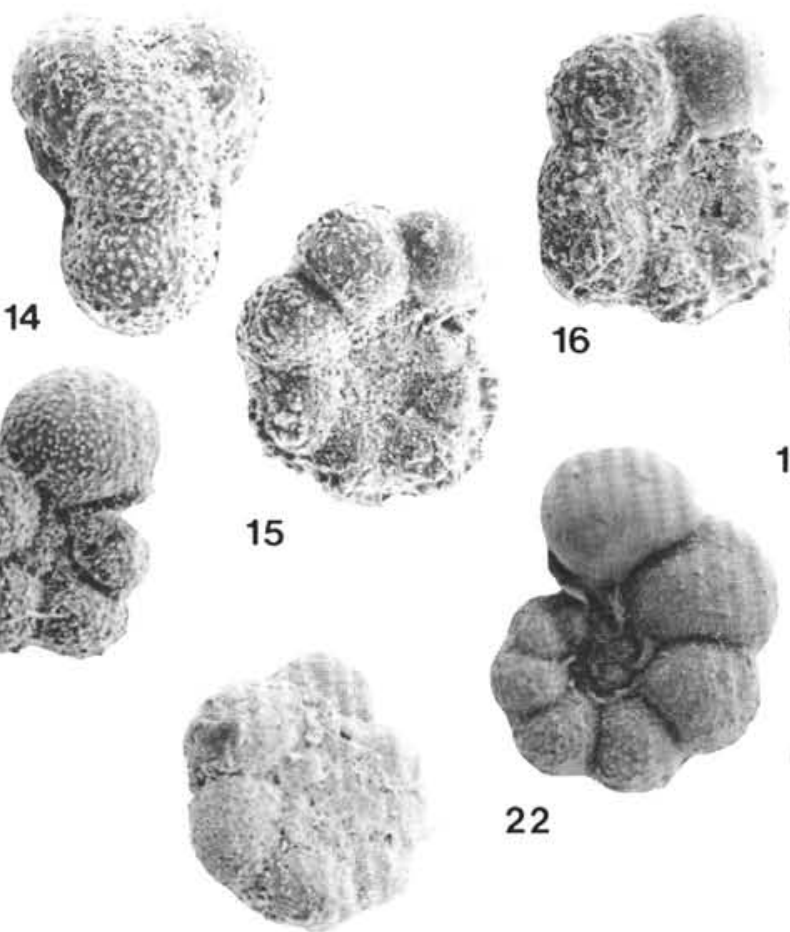

21

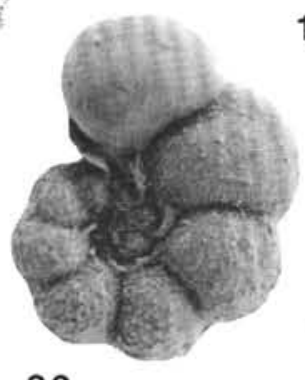

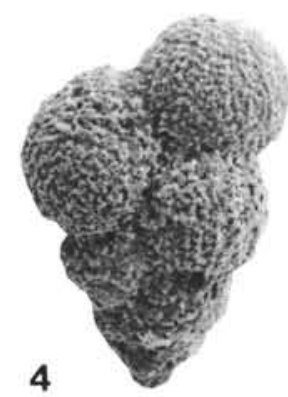

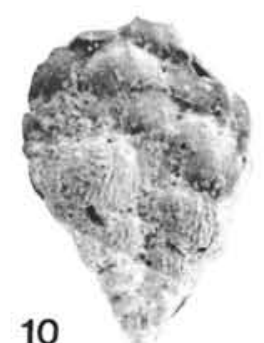

5
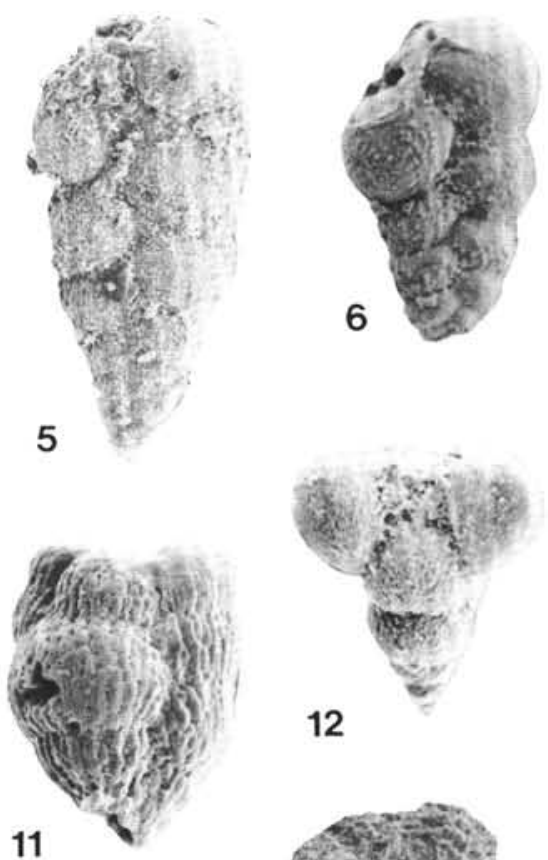

12

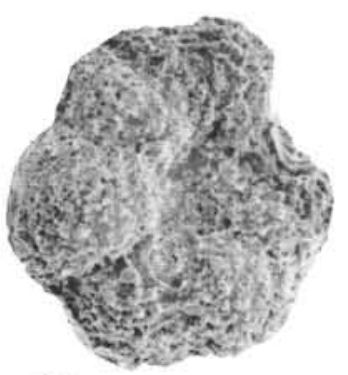

19

18
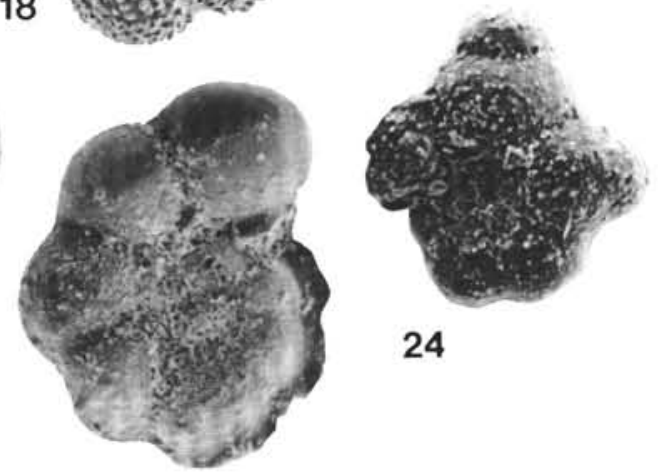

24 120-750A-17R-2, 28-32 cm, CPC 28977, ×95. 3, 4. Heterohelix globulosa (Ehrenberg); (3) Sample 120-747A-21X-3, 40-42 cm, CPC 28978, $\times 140$; (4) Sample 120-747C-9R-1, 38-40 cm, CPC 28979, $\times 200$. 5. Heterohelix aff. moremani (Cushman), Sample 120-750B-9W-2, 37-39 cm, CPC $28980, \times 155$. 6. Heterohelix navarroana Loeblich, Sample 120-747A-27X-4, 28-32 cm, CPC 28981, $\times 155$. 7. Heterohelix planata (Cushman), Sample 120-747A-21X-2, 60-62 cm, CPC 28982, $\times 90.8$. Heterohelix reussi (Cushman), Sample 120-747A-27X-2, 28-32 cm, CPC $28983, \times 125.9$. Heterohelix semicostata (Cushman), Sample 120-750A-15R-CC, CPC 28984, $\times 80$. 10. Heterohelix sp., Sample 120-750A-16R-2, 28-32 cm, CPC 28985, $\times 75$. 11. Pseudotextularia deformis (Kikoine), Sample 120-750A-15R-CC, CPC 28986, $\times 105$. 12. Racemiguembelina fructicosa (Egger), Sample 120-750A-16R-3, 28-32 cm, CPC 28987, $\times 145$. 13. Gublerina sp., Sample 120-750A-19R-3, 28-32 cm, CPC 28988, $\times 65$. 14. Biglobigerinella sp., Sample 120-747A-23X-1, 28-32 cm, CPC $28989, \times 145$. 15, 16. Globigerinelloides impensus Sliter; (15) Sample 120-747C-7R-CC, CPC 28990, ×155; (16) Sample 120-747C-6R-CC, CPC 28991, ×160. 17, 18. Globigerinelloides multispinatus (Lalicker), Sample 120-747A-22X-2, 28-32 cm, CPC 28992, $\times 170$. 19. Globigerinelloides prairiehillensis Pessagno, Sample 120-750A-18R-2, 51-55 cm, CPC 28993, $\times 120$. 20. Globigerinelloides subcarinatus (Brönnimann), Sample 120-750A-16R-2, 28-32 cm, CPC 28994, $\times 135$. 21. Globigerinelloides ultramicra (Subbotina), Sample 120-750B-9W-2, 37-39 cm, CPC 28995, ×135. 22. Globigerinelloides sp. 1, Sample 120-747A-23X-7, 28-32 cm, CPC 28996, $\times 180$. 23. Globigerinelloides sp. 2, Sample 120-747A-24X-5, 37-39 cm, CPC 28997, $\times 160$. 24. Hastigerinoides subdigitata (Carman), Sample 120-750A-21R-1, 28-32 cm, CPC 28998, $\times 190$. 


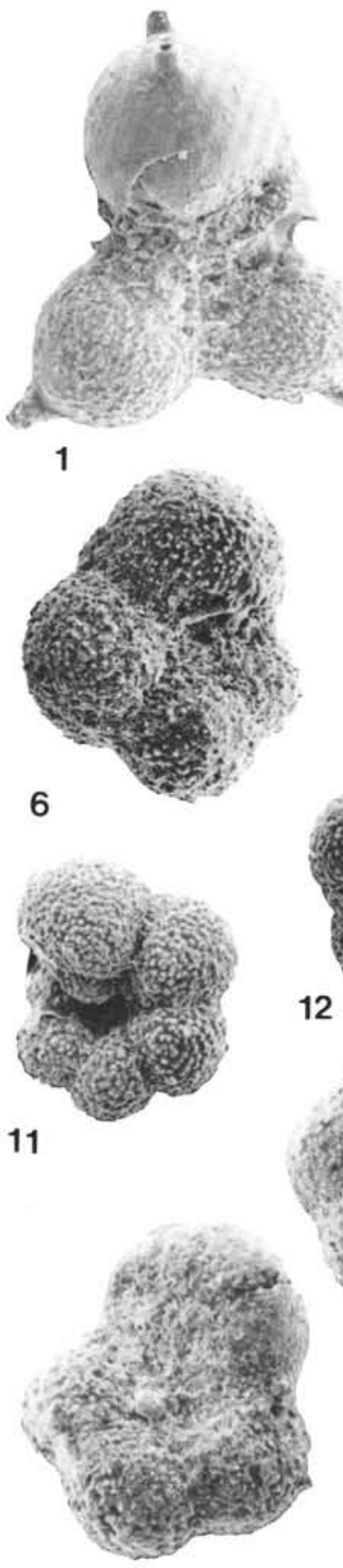

17

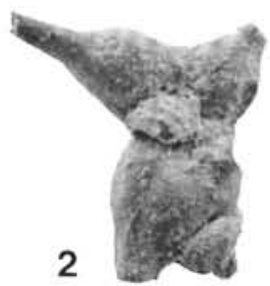

thes.

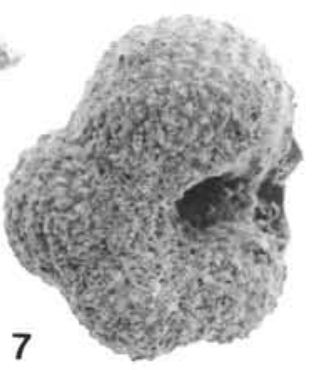

8

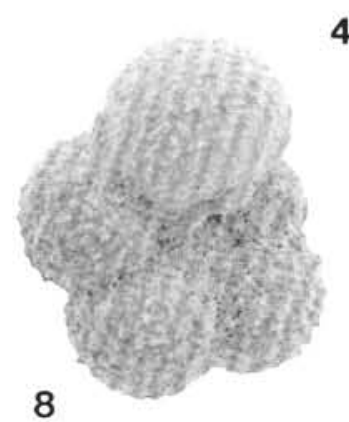

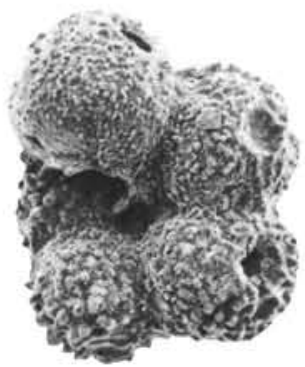

4

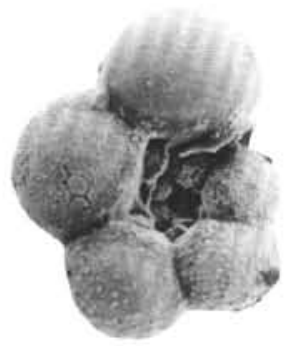

5

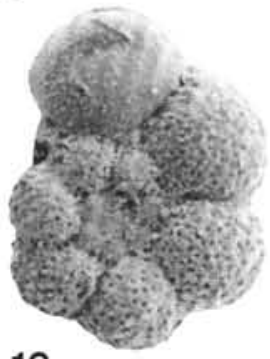

10
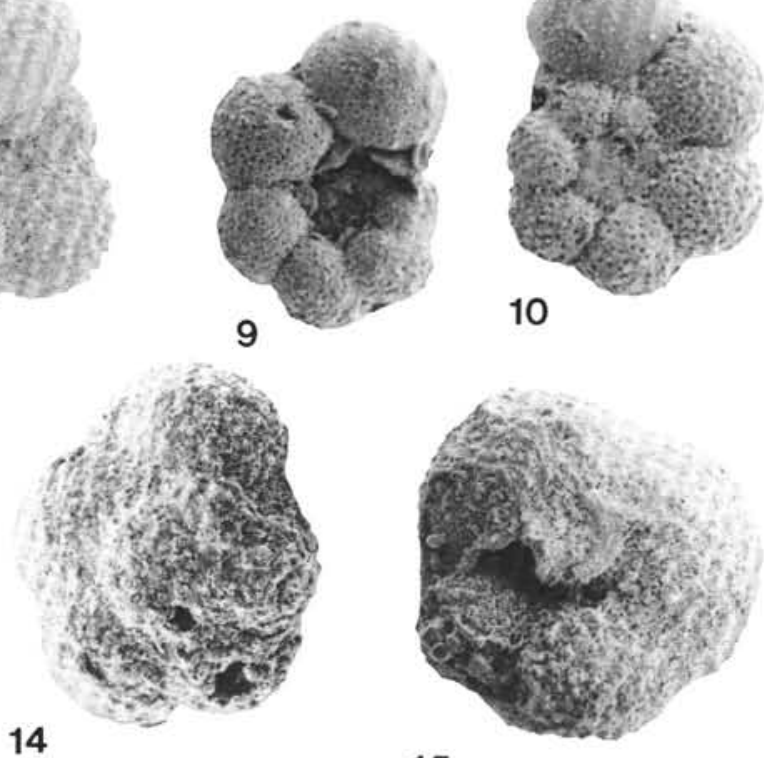

15

Plate 2. 1, 2. Schackoina multispinata (Cushman and Wickenden); (1) Sample 120-747A-24X-3, 26-30 cm, CPC 28999, $\times 200$; (2) Sample 120-747A-26X-2, 28-32 cm, CPC 29000, $\times 330$. 3. Schackoina sp., Sample 120-750A-16R-4, 28-32 cm, CPC 29001, $\times 240.4$. Hedbergella amabilis Loeblich and Tappan, ventral, Sample 120-750B-11W-CC, CPC 29002, $\times 235$. 5. Hedbergella holmdelensis Olsson, ventral, Sample 120-747A-22X-6, 28-32 cm, CPC 29003, ×300. 6-8. Hedbergella aff. monmouthensis (Olsson); (6) ventral, Sample 120-747A-24X-2, 60-62 cm, CPC 29004, $\times 155$; (7) ventral, $\times 190$; (8) ventral, $\times 165.9$, 10. Hedbergella sliteri Huber, Sample 120-747A-23X-CC, CPC 29005; (9) ventral, $\times 125$; (10) dorsal, $\times 130$. 11, 12. Hedbergella sp. 1, Sample 120-747A-27X-1, 28-32 cm, CPC 29006; (11) ventral, $\times 105 ;(12)$ dorsal, $\times 110$. 13, 14 . Whiteinella archaeocretacea Pessagno, Sample 120-750B-11W-2, $128 \mathrm{~cm}$, light, CPC 29007; (13) ventral, $\times 140 ;(14)$ dorsal, $\times 155$. 15, 18. Whiteinella baltica (Douglas and Rankin); (15) Sample 120-750B-10W-1, $60 \mathrm{~cm}$, CPC 29008, ventral, $\times 150$; (18) Sample 120-750B-10W-1, 60 cm, CPC 29009, $\times 160$. 16, 17. Whiteinella inornata (Bolli), Sample 120-750B-11W-CC, CPC 29010; (16) ventral, $\times 130 ;(17)$ dorsal, $\times 120$. 19-21. Praeglobotruncana delrioensis (Plummer), Sample 120-750B-11W-CC, CPC 29011; (19) ventral, $\times 85 ;(20)$ profile and margin, $\times 70 ;(21)$ dorsal, $\times 80$. 

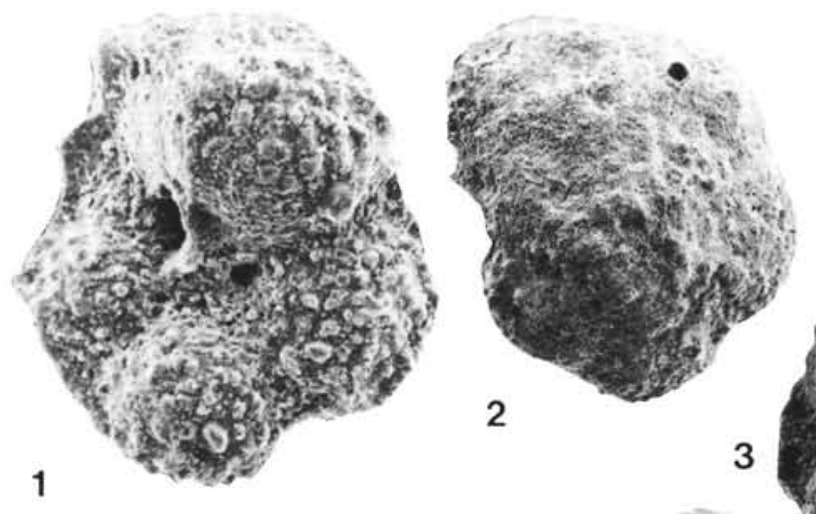

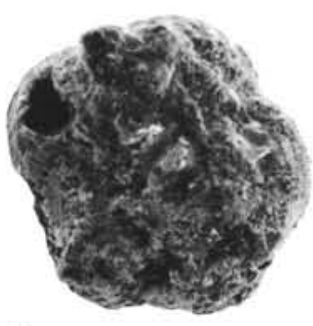

6
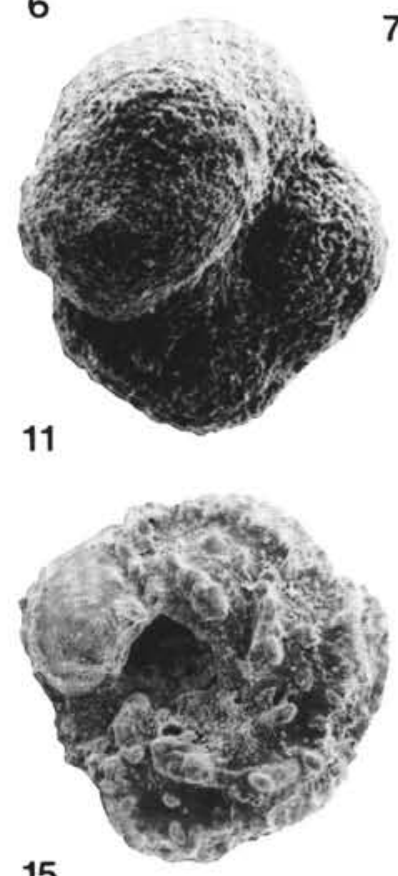

15

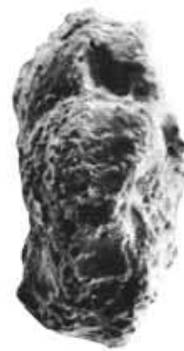

7

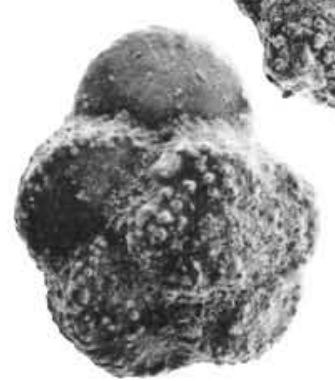

8

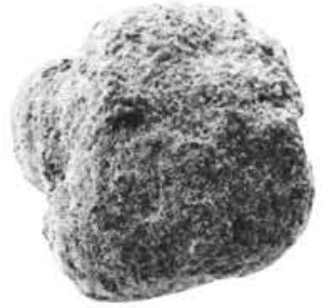

12

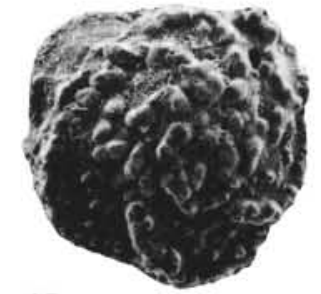

16

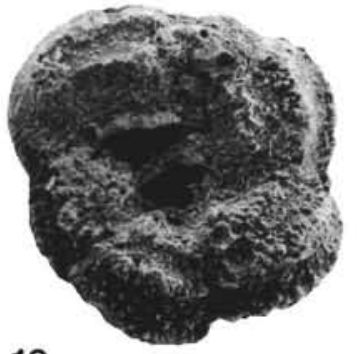

13

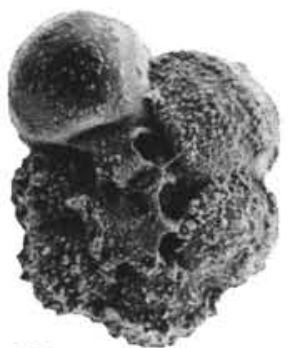

17

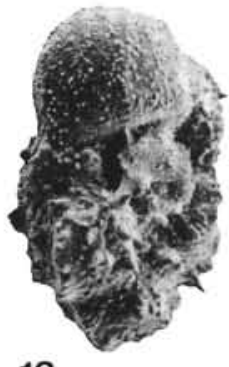

18
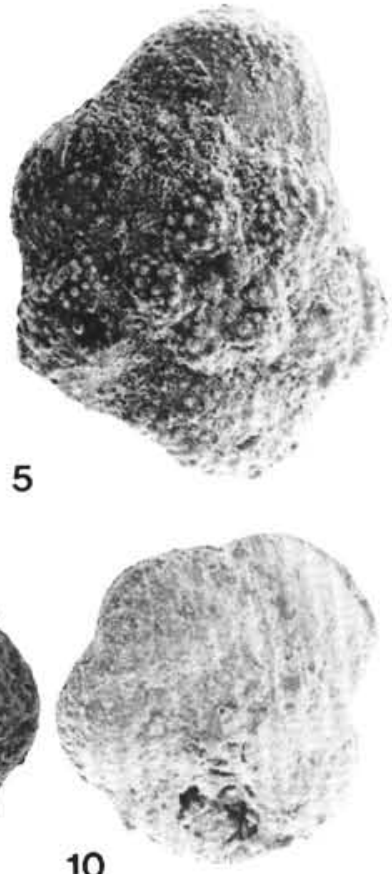

10

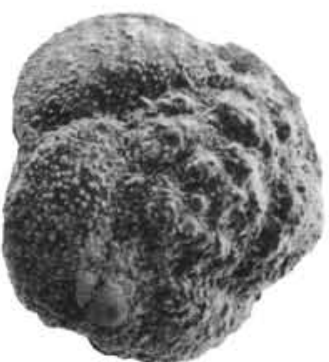

14

Plate 3. 1, 2. Praeglobotruncana cf. delrioensis (Plummer), Sample 120-750B-11W-light, CPC 29012; (1) ventral, $\times 250$; (2) dorsal, $\times 80$. 3-5. Concavatotruncana algeriana (Caron), Sample 120-750B-9W-2, 37-39 cm, CPC 29013; (3) ventral, $\times 125 ;(4)$ profile, $\times 120$; (5) dorsal, $\times 125$. 6-8. Concavatotruncana canaliculata (Reuss), Sample 120-747C-10R-CC; CPC 29014, ×110; (6) ventral; (7) profile; (8) dorsal. 9, 10. Concavatotruncana imbricata (Mornod), Sample 120-750B-11W-CC, CPC 29015, ×90; (9) ventral; (10) dorsal. 11, 12. Helvetoglobotruncana sp., Sample 120-750B-11W-2, light, CPC 29016; (11) ventral, $\times 120 ;(12)$ dorsal, $\times 105.13,14$. Contusotruncana fornicata (Plummer), Sample 120-750A-18R-1, 51-55 cm, CPC 29017, $\times 75$; (13) ventral; (14) dorsal. 15, 16. Globotruncana arca (Cushman), Sample 120-750A-23W-CC, CPC 29018; (15) ventral, $\times 95$; (16) dorsal, $\times 80$. 17-19. Globotruncana bulloides Vogler, Sample 120-747A-22X-CC, CPC 29019; (17) ventral, $\times 85$; (18) profile, $\times 100$; (19) dorsal, $\times 65$. 

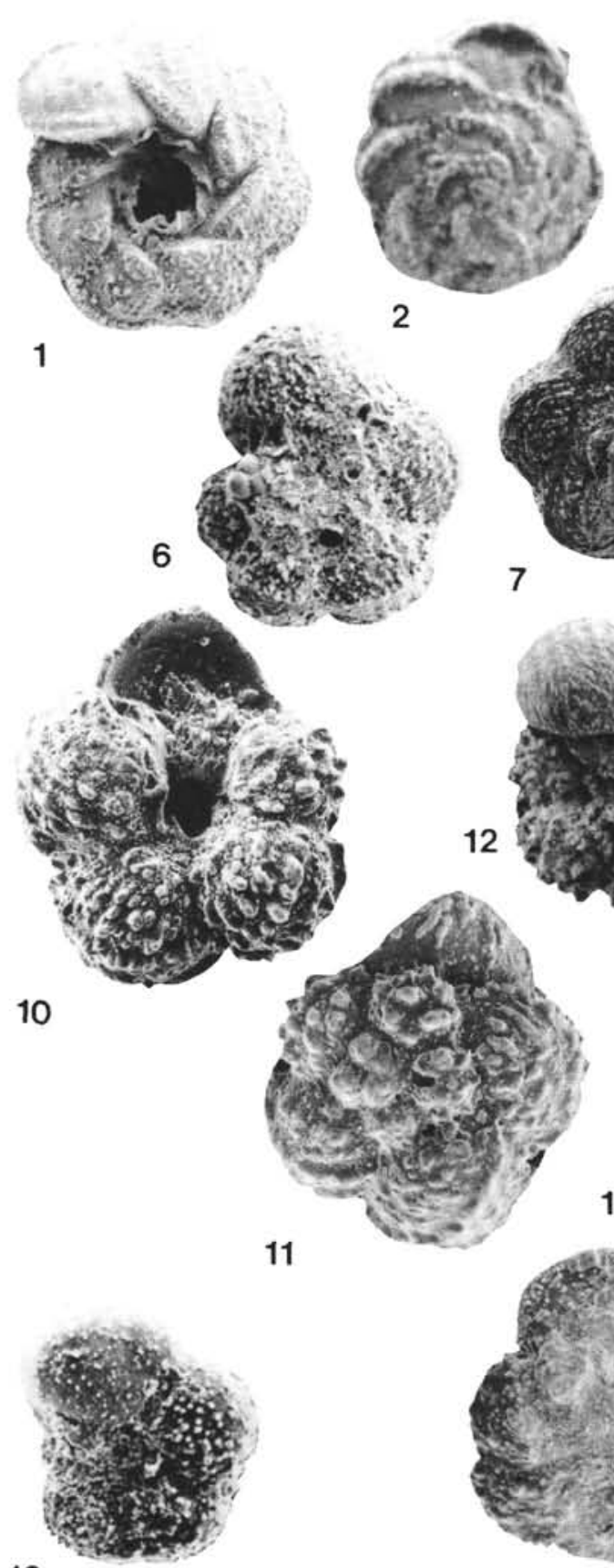

16

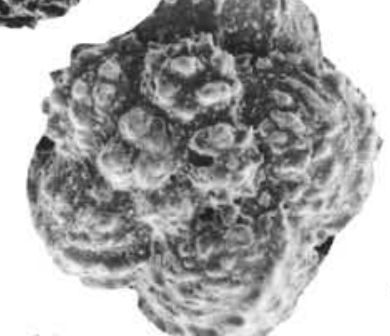

17
2

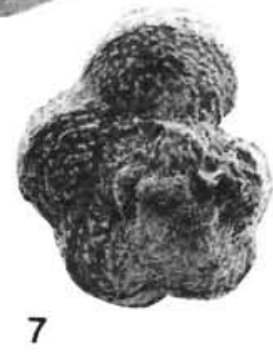

,
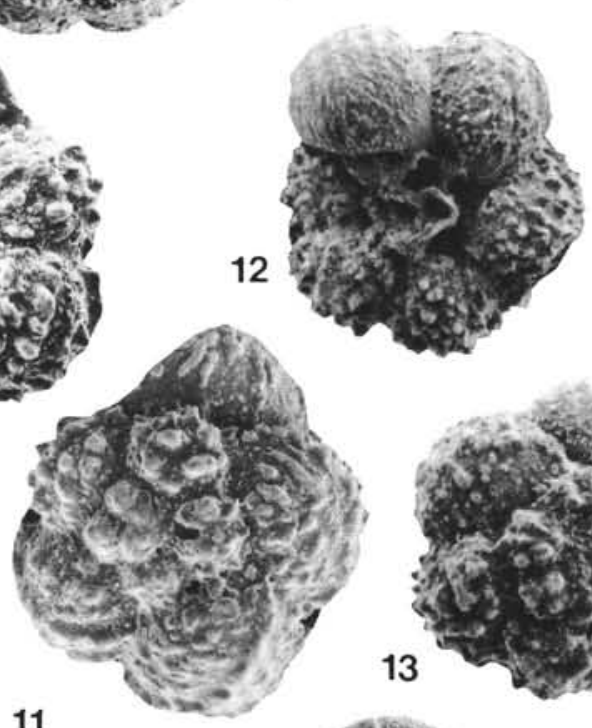
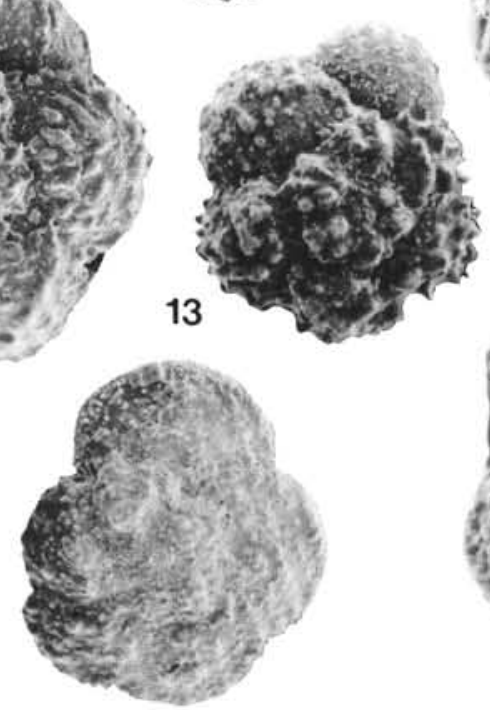
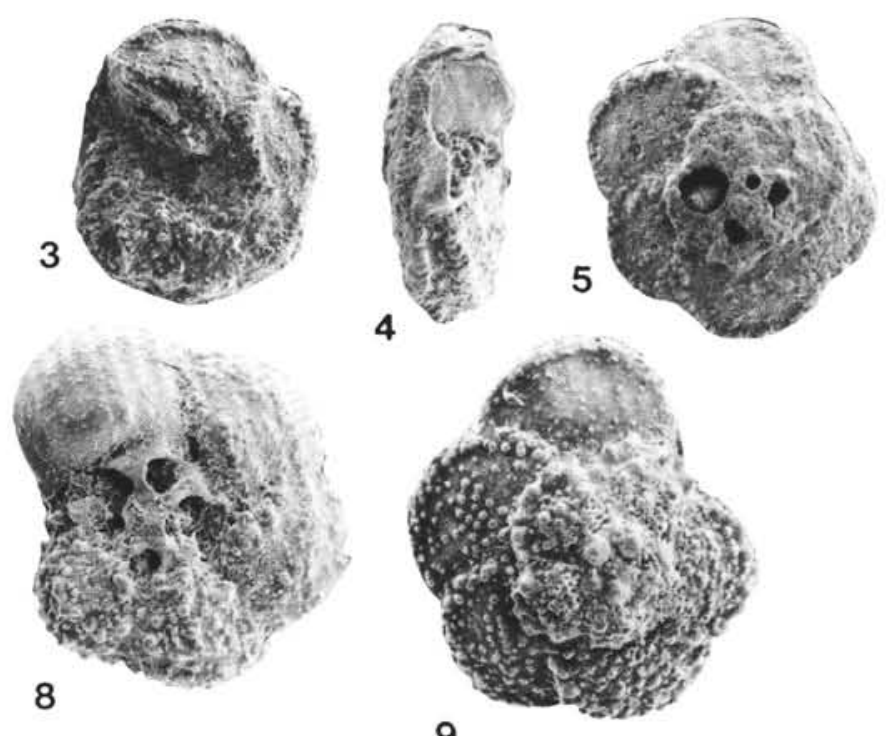

9
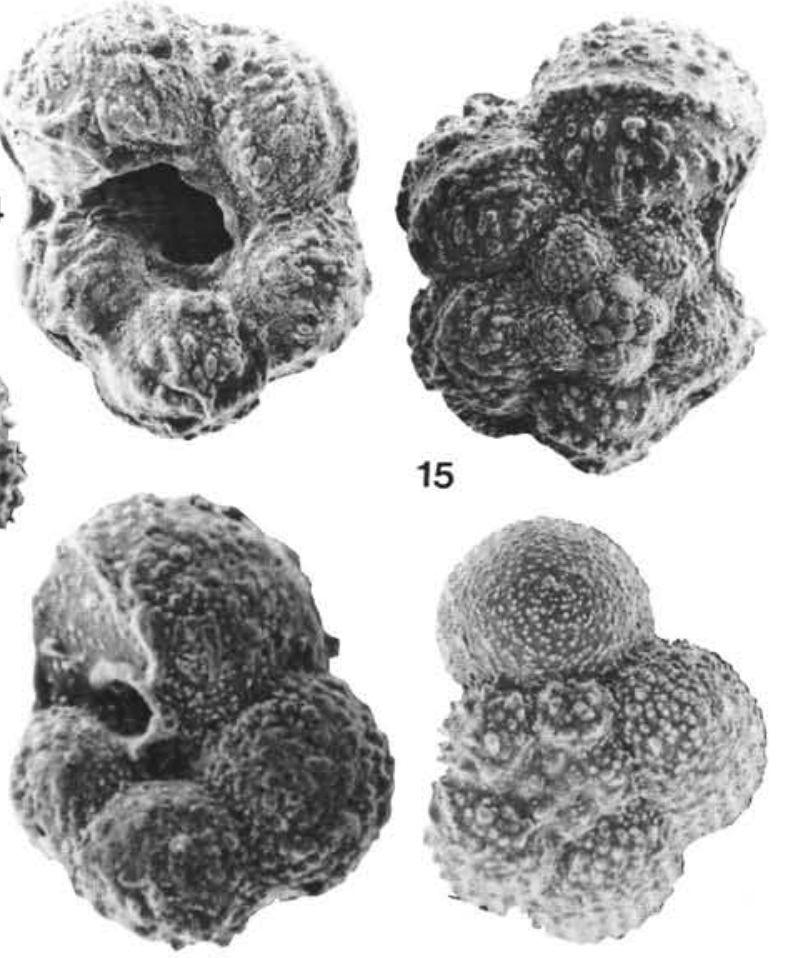

18

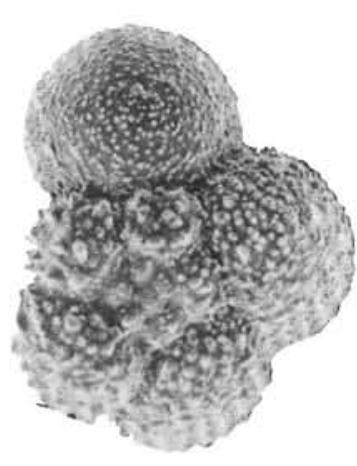

19

Plate 4. 1, 2. Globotruncana falsostuarti (Sigal), Sample 120-747A-26X-CC, CPC 29020, ×60; (1) ventral; (2) dorsal. 3-5. Globotruncana linneiana (d'Orbigny), Sample 120-750B-11W-2, 128-130 cm, CPC 29021, ×75; (3) ventral; (4) profile; (5) dorsal. 6, 7. Marginotruncana globigerinoides Brotzen, Sample 120-750A-19R-3, 28-32 cm, CPC 29022; (6) ventral, $\times 70 ;(7)$ dorsal, $\times 60.8$, 9. Marginotruncana stephensoni (Pessagno), Sample 120-750A-20R-CC, CPC 29023, ×100; (8), ventral; (9) dorsal. 10, 11. Rugotruncana aff. subpennyi (Gandolfi), Sample 120-750A-20R-CC, CPC 29025, $\times 100$; (10), ventral; (11), dorsal. 12, 13. Rugotruncana subpennyi (Gandolfi), Sample 120-750A-19R-CC, CPC 29026, $\times 105$; (12) ventral; (13) dorsal. 14, 15. Rugotruncana circumnodifer (Finlay), Sample 120-747A-22X-2, 28-32 cm, CPC 29027; (14) ventral, $\times 75$; (15) dorsal, $\times 95.16,17$. Globotruncanella citae (Bolli); (16) Sample 120-750A-21R-1, 28-32 cm, CPC 29024, ventral, $\times 160$; (17) Sample 120-747A-21X-2, 60-62 cm, CPC 29028, dorsal, $\times 145$. 18, 19. Globotruncanella havanensis (Voorwijk); (18) Sample 120-750A-18R-CC, CPC 29029, ventral, $\times 245$; (19) Sample 120-747A-23X-CC, CPC 29030, dorsal, $\times 110$. 

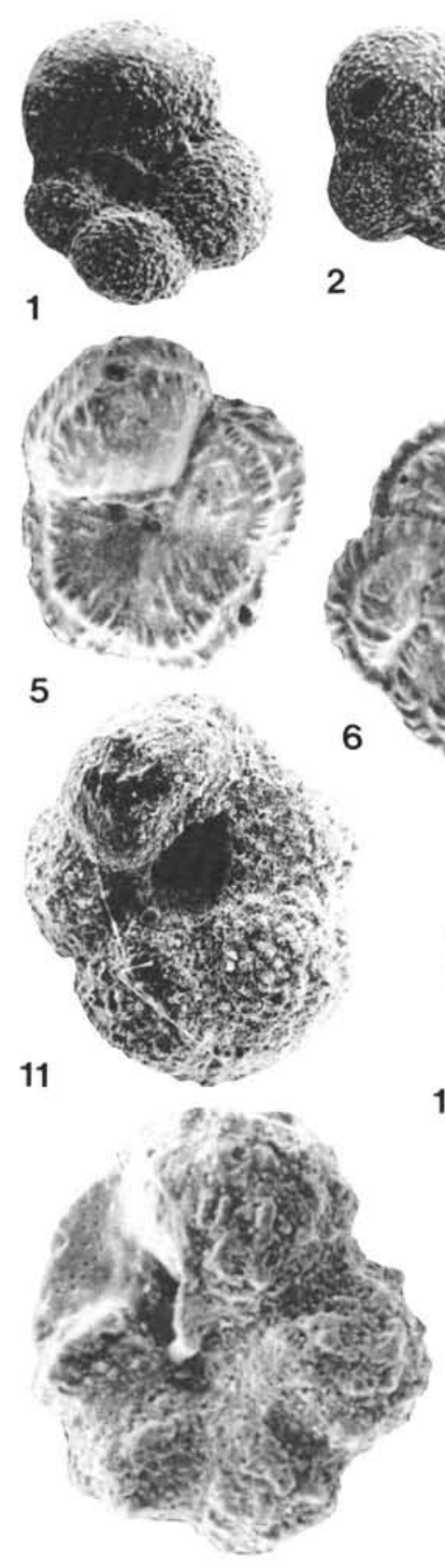

15

2
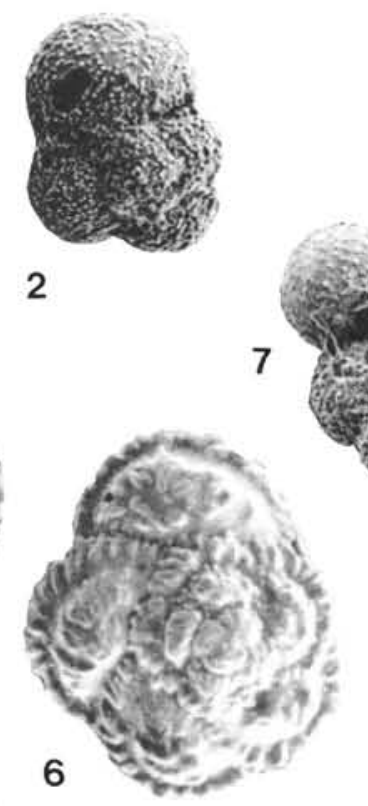

.
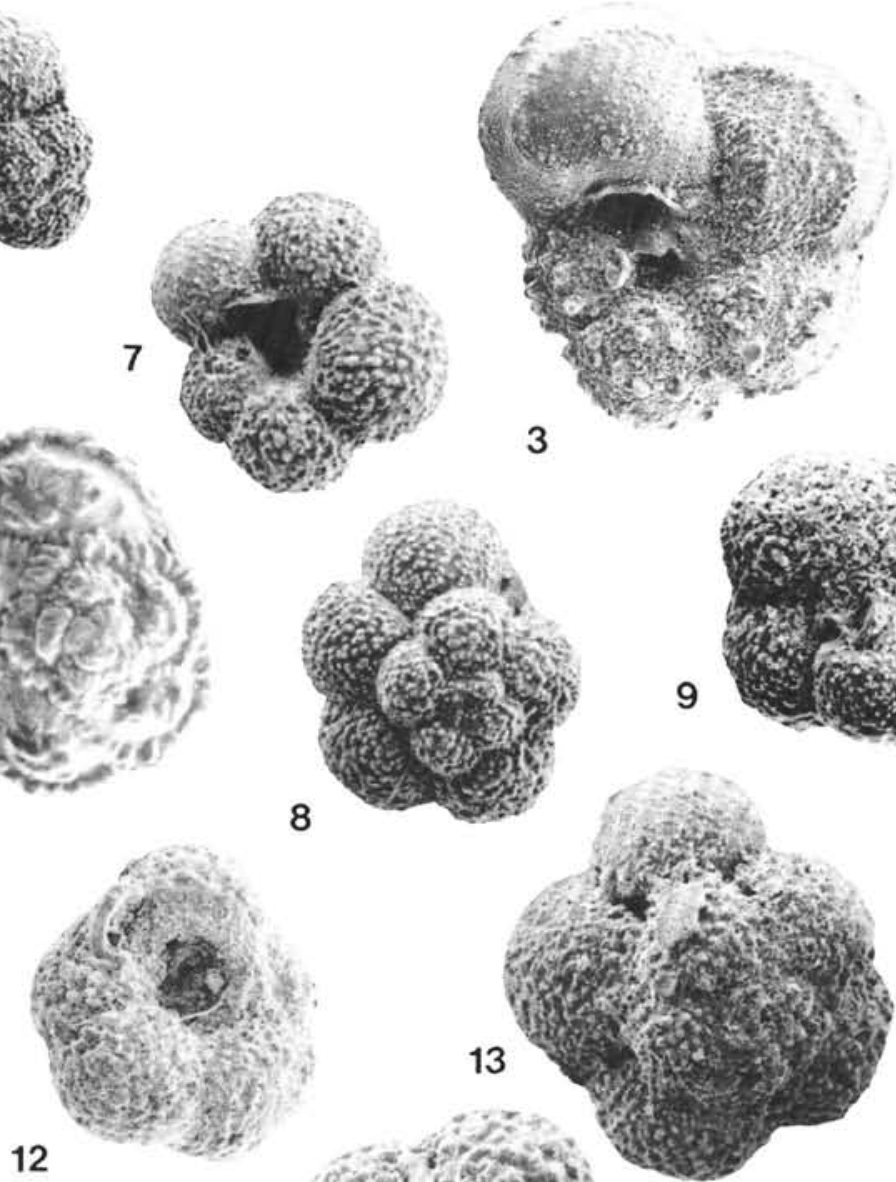

3

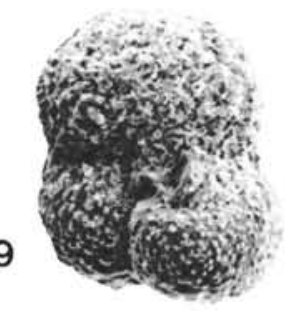

4
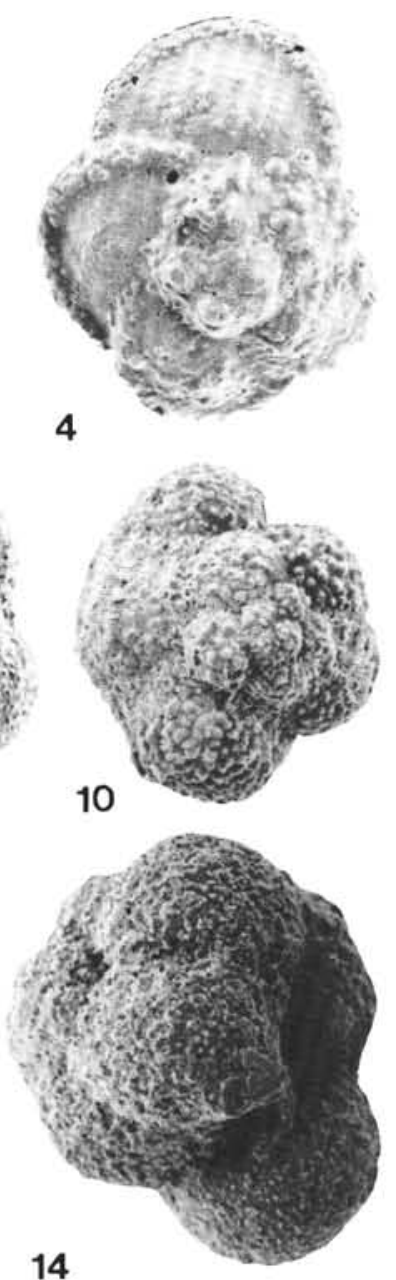

17

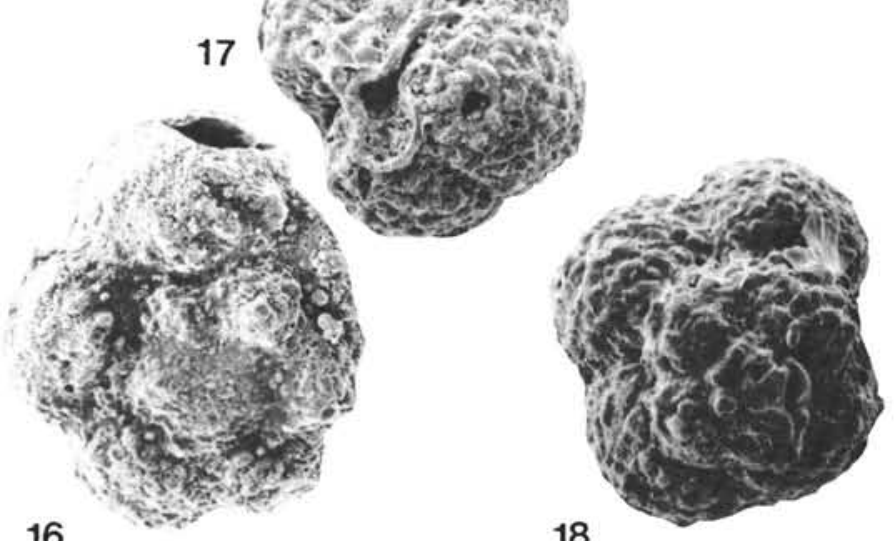

18

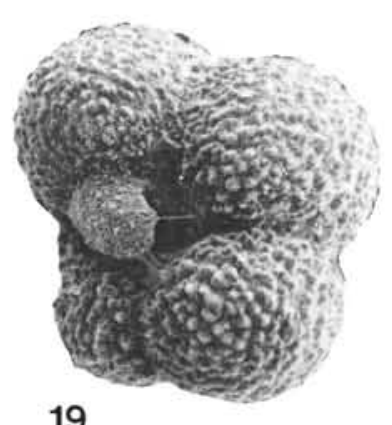

19

Plate 5. 1, 2. Globotruncanella petaloidea (Gandolfi), Sample 120-750A-16R-2, 28-32 cm, CPC 29031, $\times 120$; (1) ventral; (2) dorsal. 3, 4. Abathomphalus intermedius (Bolli), Sample 120-750A-17R-3, 28-32 cm, CPC 29032, $\times 120$; (3) ventral, (4) dorsal. 5, 6. Abathomphalus mayaroensis (Bolli), Sample 120-750A-15R-CC, CPC 29033, $\times 75$; (5) ventral; (6) dorsal. 7, 8. Archaeoglobigerina australis Huber, Sample 120-747A-22X-2, 28-32 cm, CPC 29034, × 100; (7) ventral; (8) dorsal. 9, 10. Archaeoglobigerina aff. blowi Pessagno, Sample 120-750A-21R-1, 28-32 cm, CPC 29035; (9) ventral, $\times 115$; (10) dorsal, $\times 180$. 11. Archaeoglobigerina bosquensis Pessagno, Sample 120-750B-10W-1, 60 cm, CPC 29036, ventral, $\times 165$. 12. Archaeoglobigerina pilula (Belford), Sample 120-750B-10W-1, $60 \mathrm{~cm}$, CPC 29037, ventral, $\times 115$. 13, 14 . Archaeoglobigerina sp. 1, Sample 120-747C-8R-1, 25-28 cm, CPC 29038; (13) ventral, $\times 145 ;$ (14) lateral, $\times 150$. 15, 16. Rugoglobigerina reicheli Brönnimann, Sample 120-750A-21R-CC, CPC 29039; (15) ventral, $\times 215$; (16) dorsal, $\times 195$. 17, 18. Rugoglobigerina aff. rugosa (Plummer), Sample 120-750A-15R-CC, CPC 29040, $\times 110$; (17) ventral; (18) dorsal. 19. Rugoglobigerina tradinghousensis Pessagno, Sample 120-747A24X-3, 26-30 cm, CPC 29041, ventral, $\times 145$. 